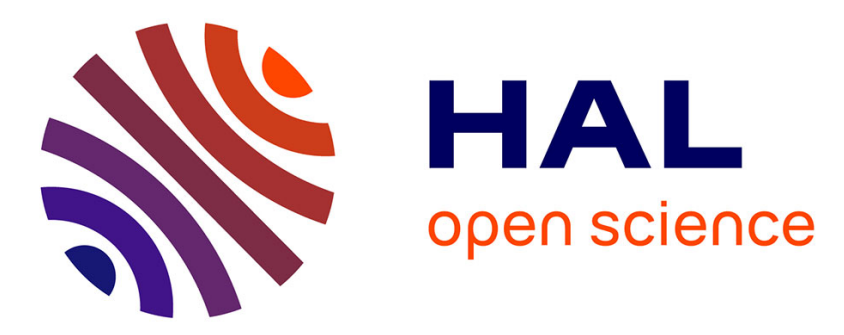

\title{
Multidentate Fluorinated Alkoxide Ligand Platforms for Oxophilic Metal Centers: From MOCVD Source Reagents to Polymerization Catalysts
}

\author{
Jean-François Carpentier
}

\section{- To cite this version:}

Jean-François Carpentier. Multidentate Fluorinated Alkoxide Ligand Platforms for Oxophilic Metal Centers: From MOCVD Source Reagents to Polymerization Catalysts. Dalton Transactions, 2010, 39 (1), pp.37-48. 10.1039/b915172a . hal-00448810

\author{
HAL Id: hal-00448810 \\ https://hal.science/hal-00448810
}

Submitted on 12 Dec 2013

HAL is a multi-disciplinary open access archive for the deposit and dissemination of scientific research documents, whether they are published or not. The documents may come from teaching and research institutions in France or abroad, or from public or private research centers.
L'archive ouverte pluridisciplinaire HAL, est destinée au dépôt et à la diffusion de documents scientifiques de niveau recherche, publiés ou non, émanant des établissements d'enseignement et de recherche français ou étrangers, des laboratoires publics ou privés. 


\title{
Multidentate fluorinated alkoxide ligand platforms for oxophilic metal centers: from MOCVD source reagents to polymerization catalysts
}

\author{
Jean-François Carpentier* \\ Received 27th July 2009, Accepted 2nd September 2009 \\ First published as an Advance Article on the web 17th September 2009 \\ DOI: 10.1039/b915172a
}

In contrast to simple fluorinated alkoxides, the coordination chemistry of multidentate ligands that incorporate $\mathrm{OC}\left(\mathrm{CF}_{3}\right)_{2} \mathrm{CR}_{2}$-type moieties and additional donors $(\mathrm{N}, \mathrm{O}$, etc. $)$ has been briefly investigated. In this Perspective, we review some well-defined, unambiguously authenticated main group and transition metal complexes supported by multidentate fluorinated alkoxide ligands and we present aspects of their syntheses, structures, and reactivities. The first part is devoted to the first syntheses of fluorinated alkoxy-imino and fluorinated alkoxy-amino ligand platforms and their application in the preparation of late transition $(\mathrm{Ru}, \mathrm{Co}, \mathrm{Ir}, \mathrm{Ni}, \mathrm{Pd}, \mathrm{Cu}$ ) and main group ( $\mathrm{Sr}, \mathrm{Ba}, \mathrm{Ga})$ metal complexes, many of which have been used as chemical vapor deposition (CVD) source reagents. In the second part, heteroleptic complexes based on oxophilic metals (Y, La, Ti, Zr, Hf, Al) and the catalytic performance of these systems in olefin polymerization and ring-opening polymerization (ROP) of cyclic esters are highlighted.

\section{Introduction and background}

Alkoxides and aryloxides (phenolates) have held a key place in the coordination chemistry of early transition metals and related oxophilic main group elements for several decades. ${ }^{1}$ Recent works, in particular those focused on the search for MOCVD precursors and new-generation polymerization catalysts, have confirmed this situation. The latter situation can be accounted for by several obvious reasons. First, alkoxides are hard, electronegative $\pi$-donor ligands, which offer strong metal-oxygen bonds that are expected to stabilize complexes of a variety of electropositive metals. Also, considerable variation in steric and electronic properties is possible thanks to the great variety of these ligands conveniently obtained from alcohols. Finally, one can also highlight that a range of

Catalysis and Organometallics, UMR 6226 Sciences Chimiques de Rennes, CNRS-University of Rennes 1, 35042, Rennes Cedex, France. E-mail: jeanfrancois.carpentier@univ-rennes1.fr; Fax: +33 (0)223-236-939

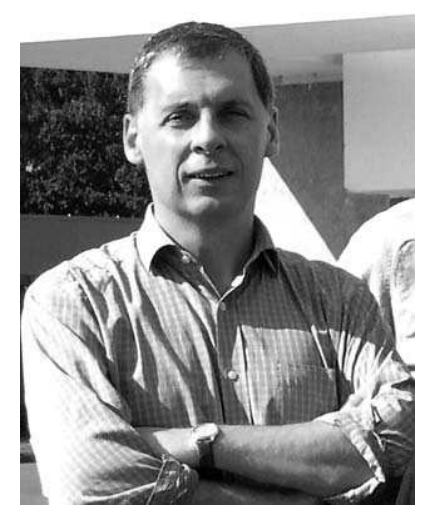

Jean-François Carpentier
Jean-François Carpentier graduated from the Chemical Engineering School of Lille in 1989 and received a $P h D$ from Lille University in 1992. After a post-doctoral internship in CEA, Tours, he returned to Lille in 1993 to take up a CNRS position. In 1997, he spent one year as research associate with Prof. Richard F. Jordan at the University of Iowa, Iowa City. In 2001, he moved to Rennes University, promoted to full Professor. His current research interests lie in the organometallic chemistry of oxophilic elements and their use in catalysis for polymer materials and fine chemicals synthesis. well-known synthetic strategies can be efficiently used, which include notably regular metathetical protocols from readily prepared alkali metal alkoxide salts and direct " $\sigma$-bond" metathesis taking profit of the acidity of the alcohol pro-ligands. However, when compared to the nowadays ubiquitous aryloxide ligands, the synthetic chemistry of oxophilic metal complexes based on simple alkoxides often proved to be much more complicated. ${ }^{1}$ This is largely due to the high tendency of the relatively more basic alkoxide ligands to act as bridging ligands, eventually resulting in (highly) aggregated structures and complex mixtures of compounds. This is especially true when large metal centers are involved.

The use of highly stable fluorinated tertiary alkoxide ligands affords an efficient strategy to overcome these difficulties. ${ }^{1 a, 2}$ The presence of strongly electron-withdrawing $\mathrm{CF}_{3}$ groups (or perfluorinated alkyl chains) $\alpha$ to the alkoxide generates intraand inter-molecular repulsions, as well as a less basic alkoxide $\mathrm{O}$ atom. Those ligands are far less $\pi$ donating than conventional alkoxides and, as a result, a much lower bridging tendency is observed, which usually leads to the selective formation of mononuclear complexes, just like phenolate ligands often do. Such a strategy has been known for years and extensively used in the chemical vapor deposition (CVD) research field to prepare volatile materials precursors. ${ }^{1,2,3}$ Most of the fluorinated alcohols used for this purpose are structurally quite simple (e.g., $\mathrm{Me}_{2}\left(\mathrm{CF}_{3}\right) \mathrm{COH}$, $\left.\mathrm{Me}\left(\mathrm{CF}_{3}\right)_{2} \mathrm{COH}, \mathrm{Ph}\left(\mathrm{CF}_{3}\right)_{2} \mathrm{COH},\left(\mathrm{CF}_{3}\right)_{3} \mathrm{COH}\right)$. As described in more detail below, recent developments in the MOCVD field are based on more sophisticated ligand platforms that include additional donors such as $\mathrm{N}$ atoms.

On the other hand, the electron-withdrawing fluorinated alkoxide residue is expected to increase the electrophilicity/Lewis acidity of the metal center, possibly conferring valuable performances for a variety of catalytic processes. However, surprisingly enough, the organometallic catalysis community has marginally exploited the rich playground of fluorinated alkoxide ligands to develop socalled "single-site" metal catalysts. Among the very few examples 
we noted by the end of the 1990s, the first relevant one was reported by Schrock et al. ${ }^{4}$ Molybdenum and tungsten imido alkylidene complexes of the type $\mathrm{M}(\mathrm{CH} t \mathrm{Bu})(\mathrm{NAr})(\mathrm{OR})(\mathrm{M}=\mathrm{Mo}$, $\left.\mathrm{W} ; \mathrm{OR}=\mathrm{OCMe}\left(\mathrm{CF}_{3}\right)_{2}, \mathrm{OCMe}_{2}\left(\mathrm{CF}_{3}\right), \mathrm{OC}\left(\mathrm{CF}_{3}\right)_{2}\left(\mathrm{CF}_{2} \mathrm{CF}_{2} \mathrm{CF}_{3}\right)\right)$ (I) were prepared and their activity for the metathesis of olefins was shown to roughly correlate with the electron-withdrawing ability of OR (Scheme 1). For instance, $\mathrm{Mo}(\mathrm{CH} t \mathrm{Bu})(\mathrm{NAr})\left[\mathrm{OCMe}_{2}\left(\mathrm{CF}_{3}\right)\right]$ promotes the metathesis of cis-2-pentene in toluene at $25{ }^{\circ} \mathrm{C}$ at a rate of $c a$. 5 turnovers per hour, that is $c a .10^{3}$ times slower than that of $\mathrm{Mo}(\mathrm{CH}-t \mathrm{Bu})(\mathrm{NAr})\left[\mathrm{OCMe}\left(\mathrm{CF}_{3}\right)_{2}\right]$, while the activity was slow to negligible when $\mathrm{OR}=\mathrm{O} t \mathrm{Bu}$. Following the same line, Grubbs et al. later prepared molybdenum and tungsten alkylidene complexes supported by a chiral chelating dialkoxide ligand derived from $(1 R, 2 R)$-1,2-bis(2-hydroxy-2,2bis(trifluoromethyl)ethyl)cyclopentane (Scheme 1). ${ }^{5}$ Simple metathetical protocols from the corresponding lithium dialkoxide salt gave selectively discrete mononuclear imido, oxo and amido complexes (II) in high yields. These group VI alkylidene complexes show excellent catalytic activity in both ring-opening metathesis polymerization (ROMP) and in ring-closing metathesis (RCM) processes. In particular, by using the molybdenum complex IIa as a catalyst, asymmetric ring-closing metathesis of racemic dienes via kinetic resolution was accomplished for the first time (Scheme 1).

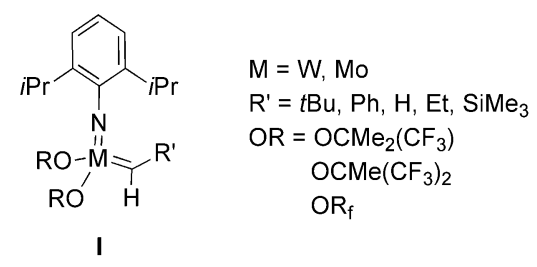

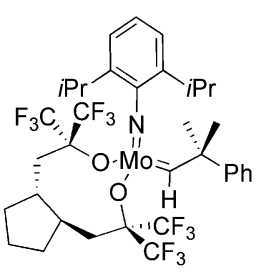

Ila

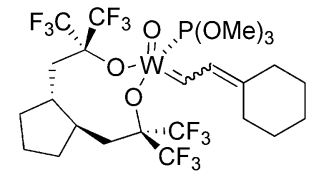

Ilb

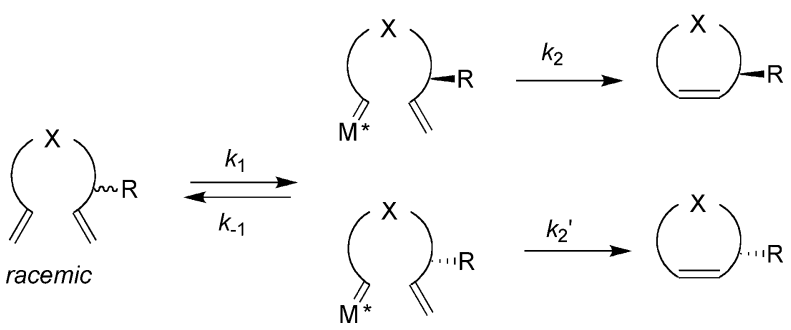

Scheme 1 Fluorinated dialkoxy-molybdenum and -tungsten alkylidene complexes and application in asymmetric ring-closing metathesis of racemic dienes. ${ }^{4,5}$

Another relevant example was reported by Jordan et al. who developed group 4 metal complexes with non-, monoor bis-fluorinated alkoxide-pyridine ligands (Scheme 2). ${ }^{6}$ Detailed studies established that neutral dibenzyl complexes $\left\{\text { pyCR }{ }^{1} \mathrm{R}^{2} \mathrm{O}\right\}_{2} \mathrm{Zr}\left(\mathrm{CH}_{2} \mathrm{Ph}\right)_{2}\left(\mathrm{R}^{1}, \mathrm{R}^{2}=\mathrm{CF}_{3}, \mathrm{CH}_{3}\right.$ or $\left.\mathrm{H}\right)($ III) adopt distorted octahedral structures with a trans-O, cis- $\mathrm{N}$, cis-benzyl

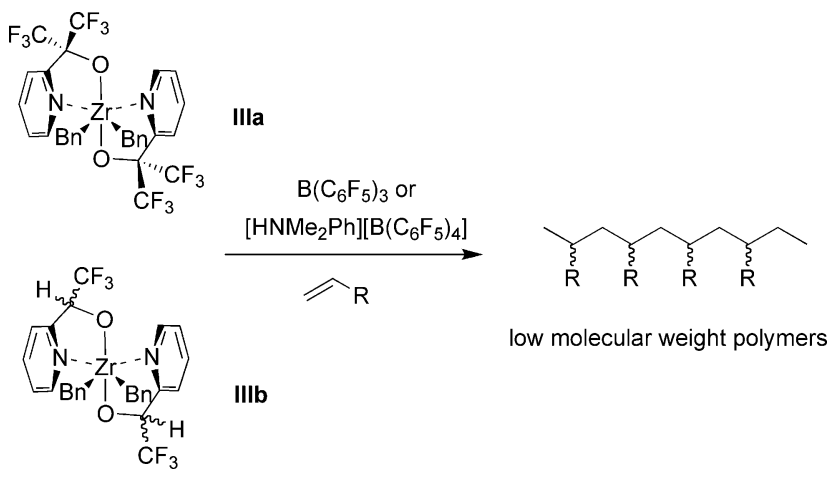

Scheme 2 Fluorinated alkoxy-pyridine zirconium complexes for olefin polymerization. ${ }^{6}$

ligand arrangement. These complexes have idealized $C_{2}$ symmetry and are, thus, chiral; however, inversion of configuration at the metal is rapid at room temperature in solution [this phenomenon proved to have a significant impact on stereoselectivity of polymerizations; vide infra]. Upon reaction with molecular activators such as $\mathrm{B}\left(\mathrm{C}_{6} \mathrm{~F}_{5}\right)_{3}$ and $\left[\mathrm{HNMe}_{2} \mathrm{Ph}\right]\left[\mathrm{B}\left(\mathrm{C}_{6} \mathrm{~F}_{5}\right)_{4}\right]$, not strongly paired ionic complexes are produced, which polymerize ethylene and 1-hexene to low molecular weight polymers. Interestingly, the mono-trifluoromethyl system $\left[\left\{\mathrm{pyCH}\left(\mathrm{CF}_{3}\right) \mathrm{O}\right\}_{2}-\mathrm{Zr}\right](\mathbf{I I I b})$ proved to be much more active for ethylene polymerization than the bis-fluorinated system $\left[\left\{\mathrm{pyC}\left(\mathrm{CF}_{3}\right)_{2} \mathrm{O}\right\}_{2}-\mathrm{Zr}\right]$ (IIIa), while the nonfluorinated system $\left[\left\{\mathrm{pyC}\left(\mathrm{CH}_{3}\right)_{2} \mathrm{O}\right\}_{2}-\mathrm{Zr}\right]$ was inactive. On the basis of the observed activity order, it was suggested that these systems may be insufficiently electrophilic to efficiently bind and activate olefins for insertion. ${ }^{6}$

In this Perspective, which is not meant to be comprehensive, we review some well-defined, unambiguously authenticated main group and transition metal complexes supported by multidentate fluorinated alkoxide ligands and we present aspects of their syntheses, structures, and reactivities. $\uparrow$ In the first part, we briefly review the first syntheses of fluorinated alkoxy-imino and fluorinated alkoxy-amino ligand platforms and their application in the preparation of late transition and main group metal complexes used as CVD source reagents. In the second part, a particular highlight is given to the preparation and performances of systems we have designed and that have been used in catalytic applications, notably in olefin polymerization and ring-opening polymerization (ROP) of cyclic esters.

\section{Discussion}

\subsection{Template syntheses of fluorinated (di)alkoxy-(di)imino complexes}

Fluorinated dialkoxy-diimino ligands of the type $\left\{\mathrm{OC}_{(} \mathrm{CF}_{3}\right)_{2}-$ $\left.\mathrm{C} \cdots \mathrm{C}=\mathrm{N} \cdots \mathrm{N}=\mathrm{C} \cdots \mathrm{C}\left(\mathrm{CF}_{3}\right)_{2} \mathrm{O}\right\}^{2-}$ were first prepared in the coordination sphere of metal ions $\left(\mathrm{Cu}^{2+}, \mathrm{Ni}^{2+}, \mathrm{Co}^{2+}, \mathrm{Ce}^{3+/ 4+}\right)$, by the template condensation of primary diamines with the fluorinated $\beta$-ketol $\mathrm{MeC}(=\mathrm{O}) \mathrm{CH}_{2} \mathrm{C}\left(\mathrm{CF}_{3}\right)_{2} \mathrm{OH}$ (Scheme 3). ${ }^{7}$ This procedure was subsequently extended to primary monoamines $\mathrm{RCH}_{2} \mathrm{NH}_{2}$, some incorporating an extra potential donor

$\uparrow$ This article refers only to $\mathrm{C} \mathrm{sp}^{3}$-hybridized fluorinated alkoxy ligand systems; i.e. containing $\mathrm{OC}\left(\mathrm{CF}_{3}\right)_{2} \mathrm{CR}_{2}$-type moieties. Systems derived from fluorinated ketoimine ligands, $\mathrm{HOC}\left(\mathrm{CF}_{3}\right)=\mathrm{CHCR}=\mathrm{NR}$, are not included. 


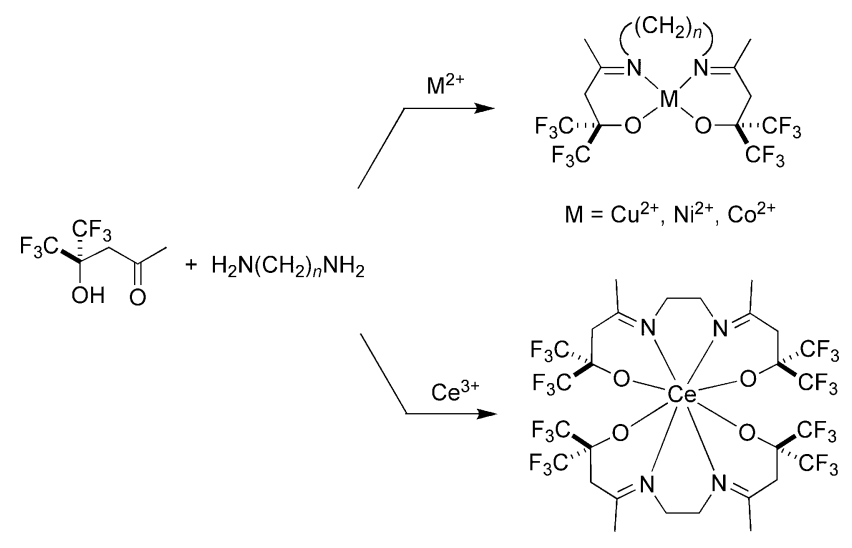

Scheme 3 Template synthesis of fluorinated dialkoxy-diimino complexes.

( $\mathrm{R}=\mathrm{NMe}_{2}$, 2-pyridyl, $\mathrm{CH}_{2} \mathrm{OCH}_{3}$ ), to prepare four- to sixcoordinated homoleptic complexes of $\mathrm{Ni}^{2+}$ (Scheme 4). ${ }^{8} \mathrm{~A}$ series of stable, neutral, fluorinated (di)alkoxy-(di)imino metal complexes was thus obtained in good yields. In the case of cerium, the initial reaction mixture contained $\mathrm{Ce}(\mathrm{III})$ (as the $\mathrm{Ce}\left(\mathrm{NO}_{3}\right)_{3} \cdot 6 \mathrm{H}_{2} \mathrm{O}$ ), and the reaction involved both the template condensation [at an eight-coordinate center] and the oxidation of $\mathrm{Ce}$ (III) to $\mathrm{Ce}(\mathrm{IV})$; the order of these steps remains, however, uncertain. ${ }^{7 \mathbf{b}}$ Such reactions with short-chain $(n=2,3)$ diamines typically proceeded in a selective manner, to afford mononuclear species that were identified by spectroscopic techniques and single-crystal X-ray diffraction studies for some of them.

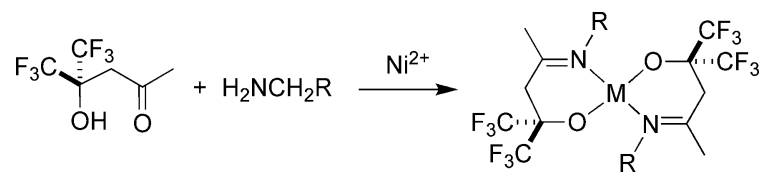

Scheme 4 Template synthesis of fluorinated alkoxy-imino complexes.

Less selective reactions were observed when longer-chain $(n=4$, $5,6,8$, or 12) diamines were used in these template condensations. ${ }^{9}$ All such compounds sublimed apparently unchanged in vacuo, and mass spectra showed strong parent ion peaks at the molecular mass values expected for mononuclear structures. However, osmometric determination of solution molecular weights gave variable results. On the basis of these data, the copper complexes were initially proposed to have exclusively a mononuclear structure in solution, with a trans arrangement of the ligands which is possible without excessive strain at a minimum value of $n=5$ (Scheme 5); however, their actual structures remained unclear and the possible existence of aggregates could not be ruled out. In fact, later X-ray diffraction studies showed that some of these compounds adopt a trans dinuclear structure in the solid state (Scheme 6). ${ }^{10}$ Similarly,<smiles></smiles>

$$
\mathrm{M}=\mathrm{Cu}^{2+}, \mathrm{Co}^{2+}, \mathrm{Ni}^{2+}
$$

Scheme 5

molar mass determinations (in acetonitrile solution) on the nickel complexes showed a change from mononuclear to dinuclear aggregation at $n \geq 4 .{ }^{9}$ Apparent association was noticed in chloroform and, more noticeably, in benzene, where concentration-dependent molecular weights up to that of a tetramer were found. Definitive evidence for the formation of aggregated species was given by the determination of the solid-state structure of a dinuclear nickel compound prepared from a $\alpha, \omega$-diamine $(n=6)$ (Scheme 6). On the basis of the similar behavior (toward added bases such as pyridine) in solution of nickel complexes with $n=5,6,8$, or 12 , it was suggested that they all have the trans dinuclear structure of the $n=6$ complex. However, a different arrangement, tentatively assigned to a cis dinuclear geometry (Scheme 6), was proposed for the $n=4$ nickel complex which is clearly different in that, although dinuclear from its molecular weight, it solvates rapidly. In all those series of compounds, the existence of an equilibrium between mononuclear and dinuclear forms was strongly suspected.

The above template methodology has been applied to the condensation of $\beta$-ketol $\mathrm{MeC}(=\mathrm{O}) \mathrm{CH}_{2} \mathrm{C}\left(\mathrm{CF}_{3}\right)_{2} \mathrm{OH}$ with aminoalcohols $\mathrm{NH}_{2}\left(\mathrm{CH}_{2}\right)_{n} \mathrm{OH}(n=2-6)^{11}$ or chiral $\beta$-substituted aminoethanols $\mathrm{NH}_{2} \mathrm{CHRCH}_{2} \mathrm{OH}{ }^{12}$ in the presence of $\mathrm{Cu}^{2+}$. Neutral alkoxy-imino complexes with a $1: 1$ metal : ligand ratio for $n=2-4$ and a $1: 2$ metal: ligand ratio for $n=5$ or 6 were obtained. Mass spectral measurements and X-ray diffraction studies showed that these compounds are associated into tetranuclear units for $n=2$, dinuclear units for $n=3$ or 4 , and mononuclear units for $n=5$ or 6 (Scheme 7). The structural data collected in those studies were used to explain diamagnetic interactions in dinuclear $\mathrm{Cu}$ (II) complexes [Cu $\cdots \mathrm{Cu}$ distances: 2.995-3.014 $\AA$ ], and supported the idea that trigonality about the bridging oxygen is important in these interactions.

Mononuclear and dinuclear complexes supported by, respectively, bidentate and tridentate fluorinated alkoxy-imino ligands were reduced with $\mathrm{LiAlH}_{4}$ to the corresponding fluorinated alkoxy-amino compounds (Scheme 8 ). ${ }^{13}$ When a chiral (racemic) amino-alcohol was used in the template synthesis, the reduction proceeded diastereoselectively, leading to $(R, R: R, R)$ and $(S, S: S, S)$ configured complexes.

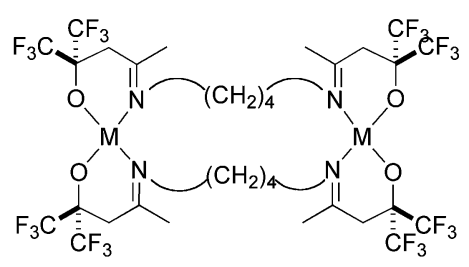

Scheme 6 


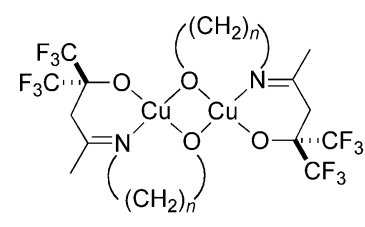

$n=3,4$

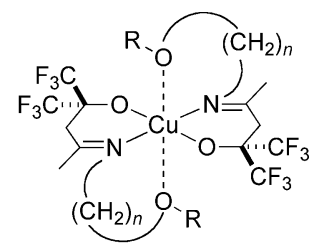

$n=5,6$
Scheme 7

\subsection{Late transition and main group metal complexes based on imino- and amino- fluorinated alkoxides for MOCVD}

The group of Chi, in collaboration with that of Carthy, thoroughly investigated the use of fluorinated alkoxy-imino and alkoxy-amino ligands to design metal organic precursors for chemical vapor deposition (MOCVD) of metal, metal oxide or fluoride thin films; the latter materials are of high interest to the microelectronics and optics industries. Families of such chelating anionic ligands were selected in order to ensure formation of stable metal interaction, while the two $\mathrm{CF}_{3}$ substituents are introduced to improve the volatility of the final metal complexes, making them more suitable for CVD investigations. Ultimately, fine tuning of the molecular structure of these complexes was intended to allow finding the best CVD reagent in the series and permit an understanding of other parameters that may influence the typical deposition processes.
In these studies, a series of $\mathrm{CF}_{3}$ disubstituted imino- and aminoalcohol pro-ligands $\mathrm{LOH}$ (e.g. $\mathrm{LO}=\mathrm{OC}\left(\mathrm{CF}_{3}\right)_{2} \mathrm{CH}_{2} \mathrm{C}(\mathrm{Me})=\mathrm{NR}$ with $\mathrm{R}=\mathrm{Me}, n \mathrm{Pr}, n \mathrm{Bu}, \mathrm{CH}_{2} \mathrm{CH}_{2} \mathrm{OMe} ; \mathrm{OC}\left(\mathrm{CF}_{3}\right)_{2} \mathrm{CH}_{2} \mathrm{NRR}^{\prime}$ with $\mathrm{R}=\mathrm{H}, \mathrm{R}^{\prime}=\mathrm{Me}, t \mathrm{Bu}, \mathrm{R}=\mathrm{R}^{\prime}=\mathrm{Me}$ ) was selected and prepared according to the procedures documented in the literature (vide infra). ${ }^{14,15}$ Then, the metal source complexes were typically obtained by mixing the corresponding alkali metal salt of anionic ligand, which was generated in situ from the reaction of the proligand with $\mathrm{NaH}$ or $\mathrm{KOH}$, and an appropriate metal chloride starting material $\left(\mathrm{Li}_{2}\left[\mathrm{PdCl}_{4}\right],[\operatorname{Ir}(\mathrm{COD})(\mu-\mathrm{Cl})]_{2},\left[\mathrm{Ru}(\mathrm{COD}) \mathrm{Cl}_{2}\right]_{x}\right.$, $\mathrm{CuCl}_{2}$ ), in THF solution at room temperature. Thus, a number of complexes based on various metal centers $\left(\mathrm{Pd},{ }^{16} \mathrm{Ir}^{17} \mathrm{Ru},{ }^{18} \mathrm{Cu}^{19}\right)$ were efficiently prepared (Scheme 9). X-Ray diffraction studies revealed in all cases monomeric compounds, with the anticipated coordination according to the type of ligand framework. For instance, the $\mathrm{Cu}(\mathrm{II})$ complex $\mathrm{Cu}\left\{\mathrm{OC}\left(\mathrm{CF}_{3}\right)_{2} \mathrm{CH}_{2} \mathrm{C}(\mathrm{Me})=\mathrm{NMe}\right\}_{2}$ shows the usual $\mathrm{N}_{2} \mathrm{O}_{2}$ square-planar geometry with the fluorinated alkoxy-imino ligand arranged in the all-trans orientation. In contrast, the complex $\mathrm{Cu}\left\{\mathrm{OC}\left(\mathrm{CF}_{3}\right)_{2} \mathrm{CH}_{2} \mathrm{CHMeNHMe}\right\}_{2}$, which bears a more flexible and sterically congested fluorinated alkoxyamino ligand, revealed a highly distorted $\mathrm{N}_{2} \mathrm{O}_{2}$ geometry with a dihedral angle of $33^{\circ}$. As expected, most of these compounds sublimed intact at relatively low temperatures. In turn, they proved to be valuable precursors for deposition of thin films made of quite pure $\mathrm{Pd},{ }^{16} \mathrm{Ir}^{17}{ }^{17} \mathrm{Ru},{ }^{18}$ and $\mathrm{Cu}^{19}$ metals with a low level of carbon and oxygen impurities, as well as polycrystalline $\mathrm{IrO}_{2}$ thin films, or even patterned $\mathrm{IrO}_{2}$ nanowires. ${ }^{17}$
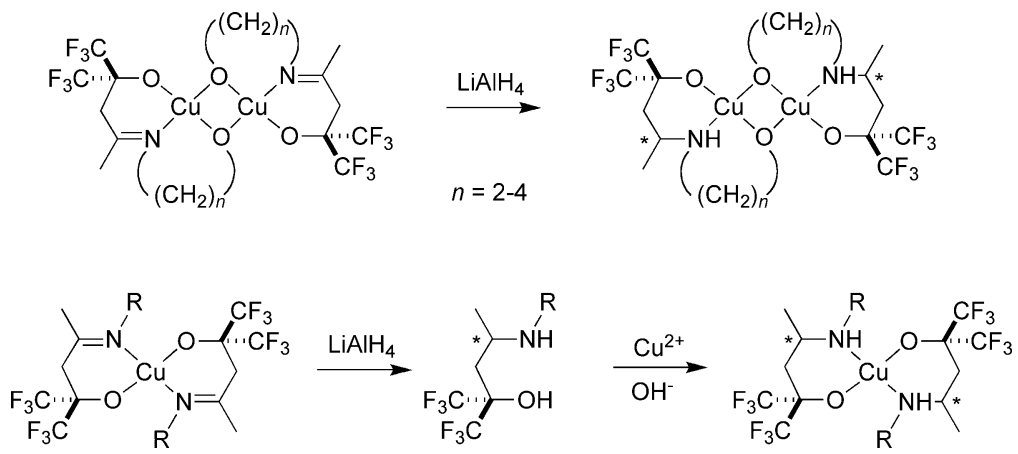

\section{Scheme 8}
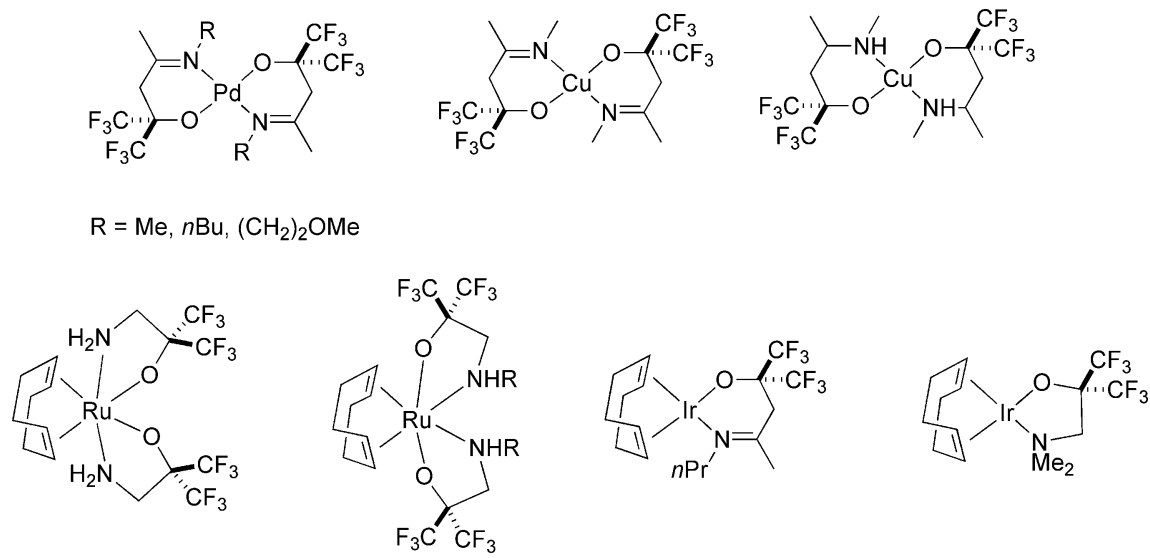

$\mathrm{R}=\mathrm{Et},\left(\mathrm{CH}_{2}\right)_{2} \mathrm{OMe}$

Scheme 9 Examples of late transition metal complexes supported by fluorinated alkoxy-amino and alkoxy-imino ligands. 
Gallium derivatives $\mathrm{Ga}\{\mathrm{OL}\}_{2} \mathrm{Cl}$, where $\mathrm{LO}=\mathrm{OC}\left(\mathrm{CF}_{3}\right)_{2}$ $\mathrm{CH}_{2} \mathrm{NMe}_{2}, \quad \mathrm{OC}\left(\mathrm{CF}_{3}\right)_{2} \mathrm{CH}_{2} \mathrm{C}(\mathrm{Me})=\mathrm{NMe}$, were similarly prepared from $\mathrm{GaCl}_{3}$ and the corresponding ligand sodium salt (Scheme 10). ${ }^{20}$ Single-crystal X-ray diffraction studies revealed mononuclear compounds in a trigonal-bipyramidal (tbp) geometry with chloride and alkoxy groups occupying the equatorial sites and the nitrogen donors located at the axial positions. Methane elimination reactions from $\mathrm{GaMe}_{3}$ and one equivalent of fluorinated amino-alcohol $\mathrm{LOH}\left(\mathrm{LO}=\mathrm{OC}\left(\mathrm{CF}_{3}\right)_{2} \mathrm{CH}_{2} \mathrm{NRR}^{\prime}\right.$ with $\mathrm{R}=\mathrm{H}, \mathrm{R}^{\prime}=\mathrm{Me}, t \mathrm{Bu}, \mathrm{R}=\mathrm{R}^{\prime}=\mathrm{Me}$ ) proceeded in high yields to afford the $\mathrm{GaMe}_{2}\{\mathrm{OL}\}$ complexes (Scheme 10). The crystal structure of such compounds showed a distorted tetrahedral framework, significantly different from the aforementioned tbp structure of $\mathrm{Ga}\{\mathrm{OL}\}_{2} \mathrm{Cl}$ complexes. Rapid $\mathrm{N}-\mathrm{Ga}$ bond scission, followed by re-coordination with possible change of the absolute configuration, in these compounds was revealed by variabletemperature ${ }^{1} \mathrm{H}$ NMR studies. For material applications, deposition of $\mathrm{Ga}_{2} \mathrm{O}_{3}$ thin films by the MOCVD process proved possible using both types of complexes $\left(\mathrm{Ga}\{\mathrm{OL}\}_{2} \mathrm{Cl}\right.$ and $\left.\mathrm{GaMe}_{2}\{\mathrm{OL}\}\right)$. Interestingly, all as-deposited films were fluorine- and chlorinefree [though they showed small amounts of carbon impurities], similar to that observed in $\mathrm{Ga}_{2} \mathrm{O}_{3}$ thin films deposited using the $\mathrm{Ga}(\mathrm{hfac})_{3}$ precursor.
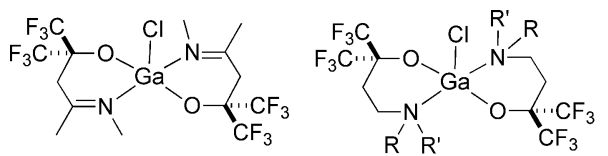

$\mathrm{R}, \mathrm{R}^{\prime}=\mathrm{H}, \mathrm{Me}, t \mathrm{Bu}$

Scheme 10 Gallium complexes supported by fluorinated alkoxy-amino and alkoxy-imino ligands.

In addition, the alkaline-earth metal homoleptic fluorinated alkoxy-amino complexes $\operatorname{Sr}\{\mathrm{OL}\}_{2}$ and $\mathrm{Ba}\{\mathrm{OL}\}_{2}$ were prepared by direct treatment of the corresponding pro-ligand $\mathrm{LOH}=$ $\mathrm{HOC}\left(\mathrm{CF}_{3}\right)_{2} \mathrm{CH}_{2} \mathrm{~N}\left(\mathrm{CH}_{2} \mathrm{CH}_{2} \mathrm{OMe}\right)_{2}$, with $\mathrm{Sr}(\mathrm{O} i \mathrm{Pr})_{2}$ and $\mathrm{BaH}_{2}$, respectively (Scheme 11). ${ }^{21}$ Single-crystal X-ray diffraction studies indicated that complex $\operatorname{Sr}\{\mathrm{OL}\}_{2}$ possesses an 8-coordinate distorted bicapped octahedral geometry with all $\mathrm{O}$ and $\mathrm{N}$ atoms coordinated to the central $\mathrm{Sr}$ cation. However, complex $\mathrm{Ba}\{\mathrm{OL}\}_{2}$ adopts a rare 10-coordinate bicapped square antiprismatic structure, of which the coordination number is increased by two fluorine-to-barium dative interactions. Variable temperature ${ }^{19} \mathrm{~F}$ NMR studies showed the existence of dynamic processes that
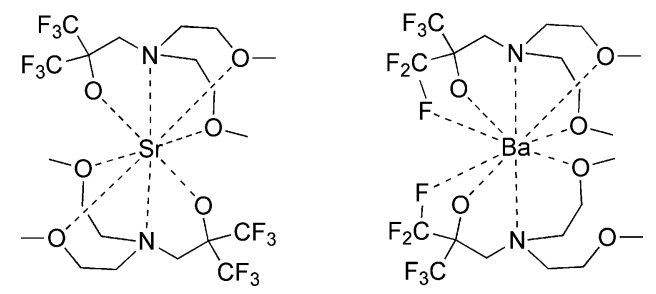

Scheme 11 Homoleptic alkaline-earth metal complexes supported by fluorinated alkoxy-amino ligands.

were attributed to the intramolecular cis-trans isomerization or the transformation between the 8-coordinate bicapped octahedral and the 10-coordinate bicapped square antiprismatic geometries. Preliminary investigations suggested that complexes $\mathrm{Sr}\{\mathrm{OL}\}_{2}$ and $\mathrm{Ba}\{\mathrm{OL}\}_{2}$ are good CVD source reagents for depositing $\mathrm{SrF}_{2}$ and $\mathrm{BaF}_{2}$ thin films, as these complexes were reasonably volatile. Those compounds represent interesting alternatives to fluorinated $\beta$-diketonate complexes which are usually employed as the CVD source reagents in this field.

\subsection{Fluorinated dialkoxy-diamino group 4 metal complexes for olefin polymerization catalysis}

Inspired by the aforementioned studies by Schrock, ${ }^{4} \mathrm{Grubbs}^{5}$ and $J^{J}{ }^{2} \mathrm{n}^{6}$ with fluorinated alkoxide ligands for group 6 and 4 metals, respectively, and in line with our own contributions on simple, nonfluorinated multidentate dialkoxide ligands for group 4 metals, ${ }^{22}$ our involvement in this chemistry started with the design of tetradentate fluorinated dialkoxy-diamino ligands. Our aim was to access ligand platforms able to support oxophilic trivalent and tetravalent metal centers and kinetically stabilize heteroleptic complexes having additional anionic ligands suitable for olefin polymerization (alkyl groups) or ring-opening polymerization of lactones and lactides (alkoxide, amido groups). At the same time, it was anticipated that the electron-withdrawing ability of the bis(trifluoromethyl) groups $\alpha$ to the alkoxide residues shall render the metal centers in those complexes more electrophilic, which in turn may be profitable for the above catalytic applications.

In collaboration with the group of Prof. Chi, we accordingly prepared diamino-diol pro-ligands $\left\{\mathrm{ON}^{\mathrm{R}} \mathrm{NO}\right\} \mathrm{H}_{2}\left(\mathrm{R}=-\left(\mathrm{CH}_{2}\right)_{2}\right.$; $-\left(\mathrm{CH}_{2}\right)_{3}-;$, 1,-cyclohexyl) by ring-opening of $\left(\mathrm{CF}_{3}\right)_{2} \mathrm{COCH}_{2}$ (in situ generated from hexafluoroacetone and diazomethane) with the corresponding secondary diamine (Scheme 12) ${ }^{23}$ Although effective, this synthetic procedure is quite tedious and dangerous,

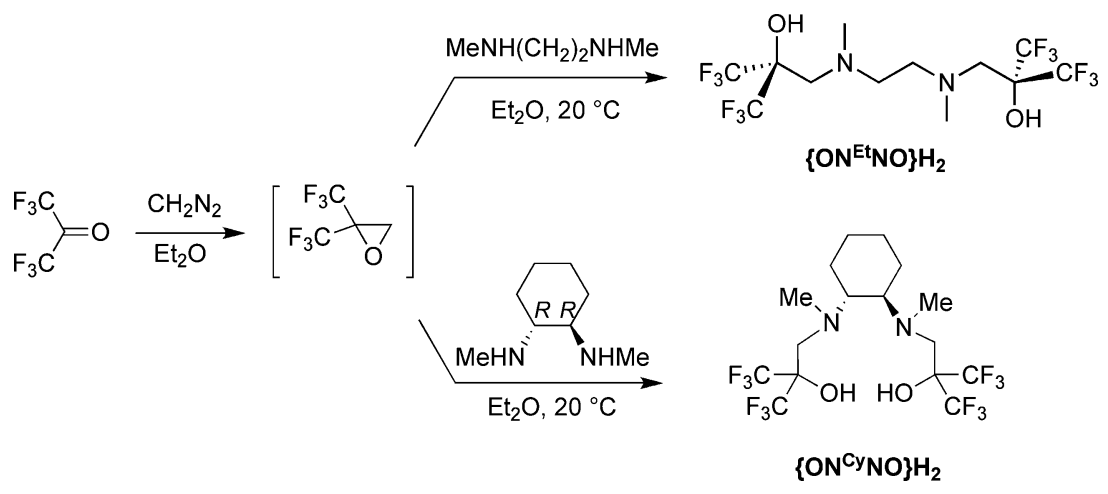

Scheme 12 Synthesis of fluorinated diamino-diol pro-ligands. 


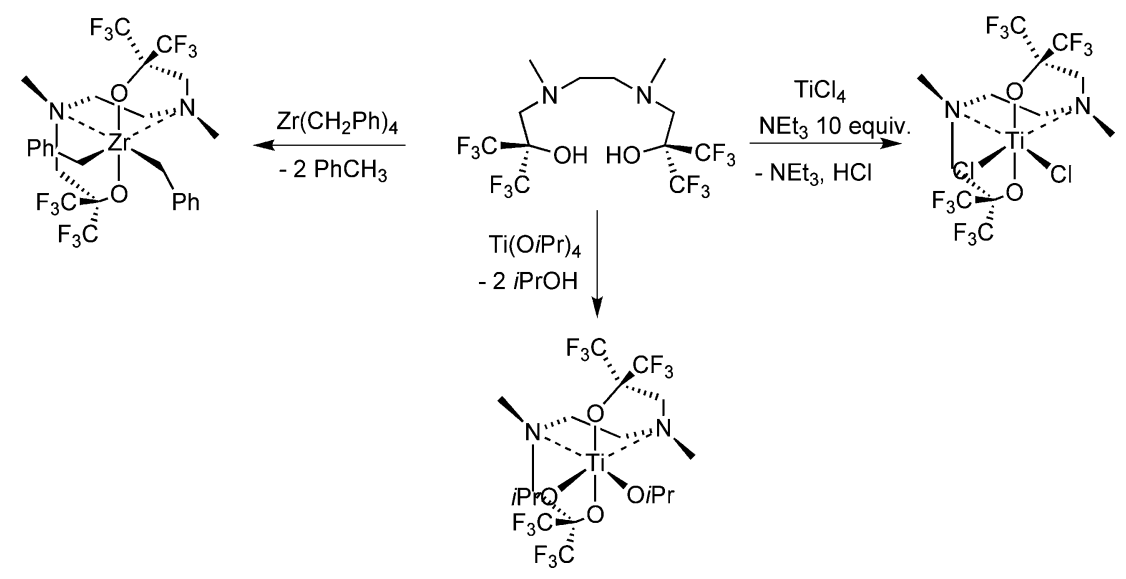

Scheme 13 Preparation of group 4 metal complexes supported by fluorinated dialkoxy-diamino ligands.

due to the high instability of the intermediate fluorinated oxirane; it must be repeated only with special care.

Thanks to their high acidity, those pro-ligands react readily under mild conditions with different homoleptic group 4 metal precursors via alcohol, alkane or amine elimination reactions. ${ }^{23}$ For instance, reactions of the ethylene-bridged $\left\{\mathrm{ON}^{\mathrm{Et}} \mathrm{NO}\right\} \mathrm{H}_{2}$ with $\mathrm{Ti}(\mathrm{O} i \mathrm{Pr})_{4}$ and $\mathrm{Zr}\left(\mathrm{CH}_{2} \mathrm{Ph}\right)_{2}$ at $-60-20{ }^{\circ} \mathrm{C}$ led to the corresponding titanium and zirconium complexes $\left\{\mathrm{ON}^{\mathrm{Et}} \mathrm{NO}\right\} \mathrm{Ti}(\mathrm{O} i \mathrm{Pr})_{2}$ and $\left\{\mathrm{ON}^{\mathrm{Et}} \mathrm{NO}\right\} \mathrm{Zr}\left(\mathrm{CH}_{2} \mathrm{Ph}\right)_{2}$. The dichlorotitanium complex $\left\{\mathrm{ON}^{\mathrm{Et}} \mathrm{NO}\right\} \mathrm{TiCl}_{2}$ was prepared by the chloride displacement reaction between $\mathrm{TiCl}_{4}$ and $\left\{\mathrm{ON}^{\mathrm{Et}} \mathrm{NO}\right\} \mathrm{H}_{2}$ in the presence of $\mathrm{NEt}_{3}$ (Scheme 13).

An interesting aspect of this study was the stereoselectivity of coordination of $\left[\mathrm{ON}^{\mathrm{R}} \mathrm{NO}^{2-}\right.$ ligands onto group 4 metal centers. X-Ray diffraction studies showed that the dichloro and dibenzyl compounds derived from the ethylene-bridged ligand adopt in the solid state a mononuclear, distorted octahedral structure with trans- $\mathrm{O}$, cis- $\mathrm{N}$, cis- $\mathrm{X}$ ligands $\left(\mathrm{X}=\mathrm{Cl}, \mathrm{CH}_{2} \mathrm{Ph}\right)$. In agreement with the solid-state structures, solution NMR data for those compounds were all consistent with a $C_{2}$-symmetric structure. It is thus remarkable that, for the four group 4 metal compounds $\left\{\mathrm{ON}^{\mathrm{R}} \mathrm{NO}\right\} \mathrm{MX}_{2}$ studied, only a single $C_{2}$-symmetric isomer (most probably a type-C structure, Scheme 14) is present at room temperature, out of the eight possible isomers. Only for $\left\{\mathrm{ON}^{\mathrm{Et}} \mathrm{NO}\right\} \mathrm{Zr}\left(\mathrm{CH}_{2} \mathrm{Ph}\right)_{2}$, a mixture of two $C_{2}$-symmetric isomers (type $\mathbf{A}$ and $\mathbf{C}$ ) was evidenced at low temperature. Since the donor properties of the $\mathrm{X}$ ligands in this series of compounds vary considerably from weak donor $(\mathrm{X}=\mathrm{Cl})$ to strong $\sigma$ donor amino $\mathrm{X}$ groups, we proposed that these structural trends reflect essentially the conformational preferences of the $\left\{O \mathrm{~N}^{\mathrm{R}} \mathrm{NO}\right\}^{2-}$ ligand.

Basically the same observations were made for compounds $\left\{\mathrm{ON}^{\mathrm{Cy}} \mathrm{NO}\right\} \mathrm{Zr}\left(\mathrm{CH}_{2} \mathrm{Ph}\right)_{2}$ and $\left\{\mathrm{ON}^{\mathrm{Cy}} \mathrm{NO}\right\} \mathrm{Ti}(\mathrm{O} i \mathrm{Pr})_{2}$ derived from the trans-1,2-cyclohexylene-bridged ligand. ${ }^{23 \mathrm{~b}}$ The dibenzyl complex $\left\{\mathrm{ON}^{\mathrm{Cy}} \mathrm{NO}\right\} \mathrm{Zr}\left(\mathrm{CH}_{2} \mathrm{Ph}\right)_{2}$ crystallizes as a $1: 1$ mixture of two diastereomers ( $\Lambda$ and $\Delta$ ), which both adopt a distorted octahedral structure with trans- $\mathrm{O}$, cis- $\mathrm{N}$, and cis- $\mathrm{CH}_{2} \mathrm{Ph}$ ligands. In toluene solution, the two diastereomers $\Lambda$ and $\Delta$ show a $C_{2}$-symmetric structure as established by NMR spectroscopy.

Variable-temperature ${ }^{1} \mathrm{H}$ and ${ }^{19} \mathrm{~F}$ NMR studies established that $\left\{\mathrm{ON}^{\mathrm{Et}} \mathrm{NO}\right\} \mathrm{Zr}\left(\mathrm{CH}_{2} \mathrm{Ph}\right)_{2}$ and $\left\{\mathrm{ON}^{\mathrm{Cy}} \mathrm{NO}\right\} \mathrm{Zr}\left(\mathrm{CH}_{2} \mathrm{Ph}\right)_{2}$ undergo inversion of metal configuration (i.e. $\Lambda / \Delta$ isomerization, racem- ization) on the NMR time scale at relatively high temperatures. The energy barrier for racemization $\left(\Delta G^{\ddagger}\right.$ (racemization)) was determined to be $17.0(1) \mathrm{kcal} \mathrm{mol}^{-1}$ in the former case, while a lower limit of $19 \mathrm{kcal} \mathrm{mol}^{-1}$ was estimated in the latter case, as coalescence of NMR resonances was not noticed up to $403 \mathrm{~K}$. These values are significantly larger than the racemization energy barrier determined for Jordan's related unbridged complex $\left\{\right.$ pyC $\left(\mathrm{CF}_{3}\right)_{2} \mathrm{O}_{2} \mathrm{Zr}\left(\mathrm{CH}_{2} \mathrm{Ph}\right)_{2}$ (IIIa, Scheme 2) ( $\Delta G^{\ddagger}$ (racemization $\left.)=8-9 \mathrm{kcal} \mathrm{mol}^{-1}\right){ }^{6}$ The observed order is consistent with the stereorigidity of the complexes, i.e. unbridged $<$ ethylenebridged $<1,2$-cyclohexylene-bridged ligand system. These values were found to be of importance to rationalize the stereoselectivity performance of these systems in 1-hexene polymerization (Scheme 15).

As a matter of fact, the neutral dibenzyl complexes $\left\{\mathrm{ON}^{\mathrm{Et}} \mathrm{NO}\right\} \mathrm{Zr}\left(\mathrm{CH}_{2} \mathrm{Ph}\right)_{2}$ and $\left\{\mathrm{ON}^{\mathrm{Cy}} \mathrm{NO}\right\} \mathrm{Zr}\left(\mathrm{CH}_{2} \mathrm{Ph}\right)_{2}(\Lambda / \Delta$ mixture), when activated with $\mathrm{B}\left(\mathrm{C}_{6} \mathrm{~F}_{5}\right)_{3}$ or $\left[\mathrm{Ph}_{3} \mathrm{C}\right]^{+}\left[\mathrm{B}\left(\mathrm{C}_{6} \mathrm{~F}_{5}\right)_{4}\right]^{-}$, are active catalysts for the polymerization of ethylene and, more interestingly, 1-hexene. ${ }^{23 \mathrm{~b}}$ The average activities determined for the system $\left\{\mathrm{ON}^{\mathrm{Et}} \mathrm{NO}\right\} \mathrm{Zr}\left(\mathrm{CH}_{2} \mathrm{Ph}\right)_{2} / \mathrm{B}\left(\mathrm{C}_{6} \mathrm{~F}_{5}\right)_{3}$ (16-62 $\mathrm{kg}$ hexene per mol $\mathrm{Zr}$ per $\mathrm{h}$ ) are of the same order as those observed with $\left\{\text { pyC }\left(\mathrm{CF}_{3}\right)_{2} \mathrm{O}\right\}_{2} \mathrm{Zr}\left(\mathrm{CH}_{2} \mathrm{Ph}\right)_{2} \quad$ (IIIa) $/ \mathrm{B}\left(\mathrm{C}_{6} \mathrm{~F}_{5}\right)_{3} \quad(90 \mathrm{~kg}$ hexene per mol $\mathrm{Zr}$ per $\left.\mathrm{h}, M_{\mathrm{n}}=840 \mathrm{~g} \mathrm{~mol}^{-1}\right){ }^{6}$ The system $\left\{\mathrm{ON}^{\mathrm{Cy}} \mathrm{NO}\right\} \mathrm{Zr}\left(\mathrm{CH}_{2} \mathrm{Ph}\right)_{2} / \mathrm{B}\left(\mathrm{C}_{6} \mathrm{~F}_{5}\right)_{3}$ features much higher activities up to $4500 \mathrm{~kg}$ hexene per mol $\mathrm{Zr}$ per $\mathrm{h}$ at $50{ }^{\circ} \mathrm{C}$, affording also higher molecular weight poly(1-hexene)s (typically, $M_{\mathrm{n}}=$ $\left.23500 \mathrm{~g} \mathrm{~mol}^{-1} ; M_{\mathrm{w}} / M_{\mathrm{n}}=1.7\right)$ with a significant level of isotactic enrichment (up to $74 \% \mathrm{mmmm} ; 84 \% \mathrm{~mm}$ ). Detailed microstructural NMR analysis of the obtained polymers indicated that an enantiomorphic-site control rather than chain-end control is operative; that is, the symmetry of the active species and not the last inserted monomeric unit is responsible for the stereoselectivity of the polymer.

Interestingly, the level of isotacticity in this series of fluorinated dialkoxide-diamino zirconium complexes appears to be related to the ease of $\Delta-\Lambda$ interconversion (vide supra): Jordan's unbridged fluorinated bis(alkoxide-pyridino) catalyst $\left\{\text { pyC }\left(\mathrm{CF}_{3}\right)_{2} \mathrm{O}\right\}_{2} \mathrm{Zr}\left(\mathrm{CH}_{2} \mathrm{Ph}\right)_{2}(\mathrm{III})$, which readily undergoes such an interconversion, yields atactic poly(1-hexene)s; ${ }^{6}$ Catalysts derived from $\left\{\mathrm{ON}^{\mathrm{Et}} \mathrm{NO}\right\} \mathrm{Zr}\left(\mathrm{CH}_{2} \mathrm{Ph}\right)_{2}$ are isotactic (up to $54 \% \mathrm{~mm}$ ) but significantly less than those derived from $\left\{\mathrm{ON}^{\mathrm{Cy}} \mathrm{NO}\right\} \mathrm{Zr}\left(\mathrm{CH}_{2} \mathrm{Ph}\right)_{2}$, 


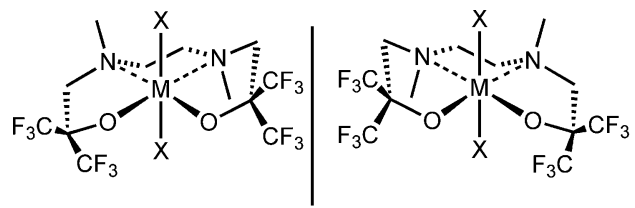

A $C_{2}$

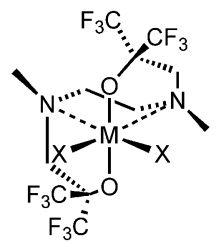

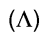

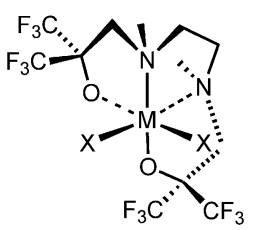

$E C_{1}$

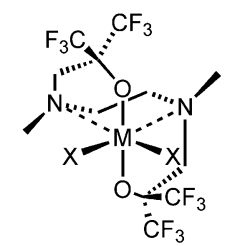

$(\Delta)$

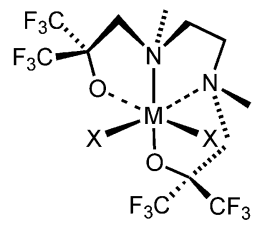

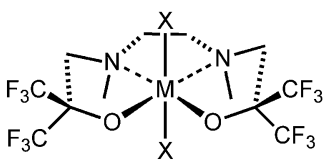

B $C_{\mathrm{s}}$

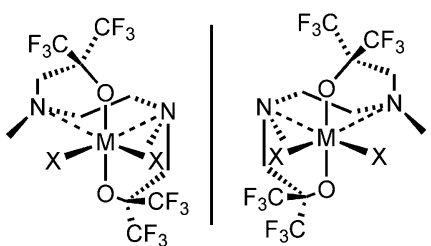

$(\Delta)$

$(\Lambda)$

D $C_{1}$

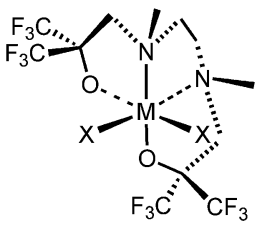

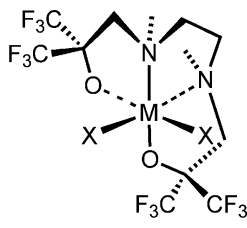

G $C_{1}$

Scheme 14 Possible isomers for octahedral group 4 metal complexes $\left\{\mathrm{ON}^{\mathrm{R}} \mathrm{NO}\right\} \mathrm{MX} \mathrm{X}_{2}$. Most complexes adopt a type-C structure in solution and in the solid state. ${ }^{23}$

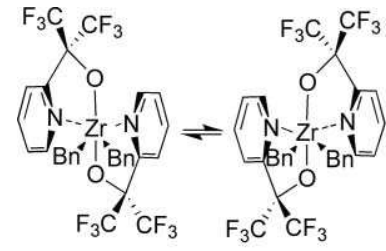

$\Delta$

$\Delta \mathrm{G}^{\#}=8-9 \mathrm{kcal}^{\mathrm{mol}}{ }^{-1}$

$\mathrm{B}\left(\mathrm{C}_{6} \mathrm{~F}_{5}\right)_{3} \downarrow=^{n \mathrm{Bu}}$

$\underbrace{R} \underbrace{R} \underbrace{R}$

atactic poly(1-hexene)

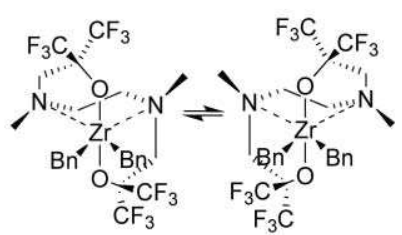

$\Delta$

$\Delta \mathrm{G}^{\#}=17 \mathrm{kcal} \cdot \mathrm{mol}^{-1}$

$\mathrm{B}\left(\mathrm{C}_{6} \mathrm{~F}_{5}\right)_{3} \downarrow=^{n \mathrm{Bu}}$

具矣苜

isotactic enriched poly(1-hexene) up to $54 \% \mathrm{~mm}$

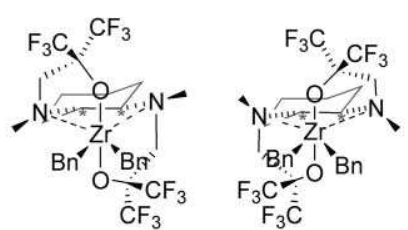

$\Delta$

$\Lambda$

$\Delta \mathrm{G}^{\#}=>19 \mathrm{kcal} \cdot \mathrm{mol}^{-1}$

$\mathrm{B}\left(\mathrm{C}_{6} \mathrm{~F}_{5}\right)_{3} \downarrow=^{n \mathrm{Bu}}$

兑矣苜苜

isotactic enriched poly(1-hexene)

up to $84 \% \mathrm{~mm}$

Scheme 15 Relationships between catalyst structure, racemization barriers and stereoselectivity in 1-hexene polymerization from $\left\{\mathrm{ON}{ }^{\mathrm{R}} \mathrm{NO}\right\} \mathrm{Zr}\left(\mathrm{CH}_{2} \mathrm{Ph}\right)_{2}$ precursors.

which is stereorigid on the NMR timescale at temperatures up to $100{ }^{\circ} \mathrm{C}$. Also, the later catalysts are significantly more regioselective, yielding poly(1-hexene)s exempt of 2,1-regiodefects.

\subsection{Fluorinated dialkoxy-diamino group 3 and 13 metal complexes for ring-opening polymerization catalysis of lactones}

Similar $\sigma$-bond metathesis reactions of the ethylene-bridged pro-ligand $\left\{\mathrm{ON}^{\mathrm{Et}} \mathrm{NO}\right\} \mathrm{H}_{2}$ with $\mathrm{Y}\left(\mathrm{CH}_{2} \mathrm{SiMe}_{3}\right)_{3}(\mathrm{THF})_{2}$ and $\mathrm{Y}\left(\mathrm{N}\left(\mathrm{SiHMe}_{2}\right)_{2}\right)(\mathrm{THF})_{2}$ afforded the corresponding yttrium compounds $\left\{\mathrm{ON}{ }^{\mathrm{Et}} \mathrm{NO}\right\} \mathrm{Y}\left(\mathrm{N}\left(\mathrm{SiHMe}_{2}\right)_{2}\right)(\mathrm{THF})$ and $\left\{\mathrm{ON}^{\mathrm{Et}} \mathrm{NO}\right\}$ $\mathrm{Y}\left(\mathrm{CH}_{2} \mathrm{SiMe}_{3}\right)(\mathrm{THF})$ (Scheme 16). ${ }^{23 \mathrm{a}}$ The reactions were, however, less selective than those based on group 4 metal precursors, as formation of small amounts of unidentified side products was observed in both cases. The isopropoxide aluminium complex $\left\{\mathrm{ON}^{\mathrm{Et}} \mathrm{NO}\right\} \mathrm{Al}(\mathrm{O} i \mathrm{Pr})$ was synthesized in a straightforward way from $\mathrm{Al}(\mathrm{O} i \mathrm{Pr})_{3}$ and was isolated in good yield (Scheme 16). ${ }^{24}$ In contrast, attempts to prepare cleanly the analogous $\mathrm{Al}-\mathrm{Me}$ complex, via reaction of $\left\{\mathrm{ON}^{\mathrm{Et}} \mathrm{NO}\right\} \mathrm{H}_{2}$ with $\mathrm{AlMe}_{3}$, remained unsuccessful although reaction clearly occurred, as evidenced by vigorous methane evolution.

Single-crystal diffraction studies revealed that $\left\{\mathrm{ON}^{\mathrm{E} t} \mathrm{NO}\right\} \mathrm{Al}-$ $(\mathrm{O} i \mathrm{Pr})$ is a monomeric compound with the $\mathrm{Al}$ center in a distorted trigonal bipyramidal coordination geometry; the $\mathrm{O} i \mathrm{Pr}$ oxygen, $\mathrm{N}$ (ligand) and $\mathrm{O}$ (ligand) lie in equatorial positions while $\mathrm{O}$ (ligand) and $\mathrm{N}$ (ligand) occupy the axial ones. Complex 

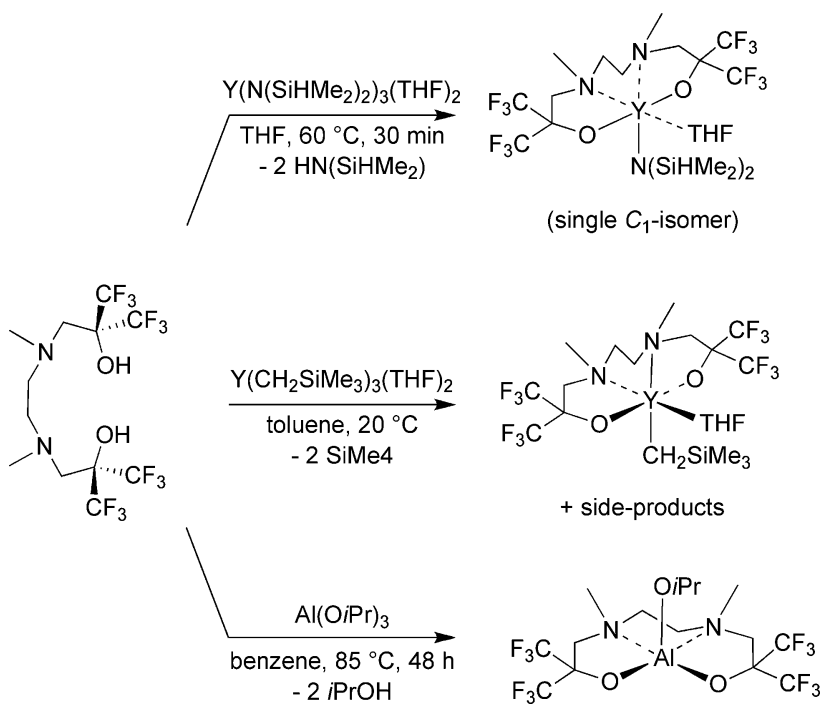

Scheme 16 Syntheses of yttrium and aluminium complexes supported by fluorinated dialkoxy-diamino ligands.

$\left\{\mathrm{ON}^{\mathrm{Et}} \mathrm{NO}\right\} \mathrm{Y}\left(\mathrm{CH}_{2} \mathrm{SiMe}_{3}\right)(\mathrm{THF})$ is seven-coordinate in the solid state, due to $\mathrm{Y} \cdots \mathrm{F}$ coordination to one of the four $\mathrm{CF}_{3}$ substituents. The bond distance of 2.806(2) $\AA$ reflects, however, a weak $\mathrm{Y} \cdots \mathrm{F}$ interaction. In agreement, the ${ }^{19} \mathrm{~F}$ NMR chemical shifts of this compound are essentially identical to the spectrum of related group 4 metal complexes $\left\{\mathrm{ON}^{\mathrm{R}} \mathrm{NO}\right\} \mathrm{MX}_{2}$ and give no indication of persistent $\mathrm{Y} \cdots \mathrm{F}$ coordination in solution. Apart from this feature that induces distortion in the octahedral coordination of the $\left\{\mathrm{ON}^{\mathrm{Et}} \mathrm{NO}\right\}^{2-}$ ligand in the solid state, $\left\{\mathrm{ON}^{\mathrm{Et}} \mathrm{NO}\right\} \mathrm{Y}\left(\mathrm{CH}_{2} \mathrm{SiMe}_{3}\right)(\mathrm{THF})$ is in other ways structurally similar to $\left\{\mathrm{ON}^{\mathrm{Et}} \mathrm{NO}\right\} \mathrm{Zr}\left(\mathrm{CH}_{2} \mathrm{Ph}\right)_{2}$ and $\left\{\mathrm{ON}^{\mathrm{Et}} \mathrm{NO}\right\} \mathrm{TiCl}_{2}$. In agreement with this observation, NMR studies conducted for $\left\{\mathrm{ON}^{\mathrm{Et}} \mathrm{NO}\right\} \mathrm{Y}\left(\mathrm{CH}_{2} \mathrm{SiMe}_{3}\right)(\mathrm{THF})$ indicated that this compound adopts a $C_{2}$-symmetric structure in solution analogous to those of the latter group 4 metal complexes $\left\{\mathrm{ON}^{\mathrm{R}} \mathrm{NO}\right\} \mathrm{MX}_{2}$. In contrast, $\left\{\mathrm{ON}^{\mathrm{Et}} \mathrm{NO}\right\} \mathrm{Y}\left(\mathrm{N}\left(\mathrm{SiHMe}_{2}\right)_{2}\right)(\mathrm{THF})$ features a $C_{1}$-symmetric structure in solution.

Complex $\left\{\mathrm{ON}^{\mathrm{Et}} \mathrm{NO}\right\} \mathrm{Al}(\mathrm{O} i \mathrm{Pr})$ was found to be an effective initiator for the ring-opening polymerization (ROP) of $\varepsilon$-caprolactone (Scheme 17). ${ }^{24}$ High polymerization activity was observed at room temperature in dichloromethane, with turnover frequencies (TOFs) in the range 200-250 $\mathrm{h}^{-1}$. These activity data compare favorably with those for the simple precursor $\mathrm{Al}(\mathrm{O} i \mathrm{Pr})_{3}$ and most discrete aluminium initiators as well, in particular related bis(phenolate) salen- and salan-type complexes. The latter compounds are usually reported to be active from $50{ }^{\circ} \mathrm{C}$ and/or afford TOFs one order of magnitude lower than $\left\{\mathrm{ON}^{\mathrm{Et}} \mathrm{NO}\right\} \mathrm{Al}(\mathrm{O} i \mathrm{Pr})$ at
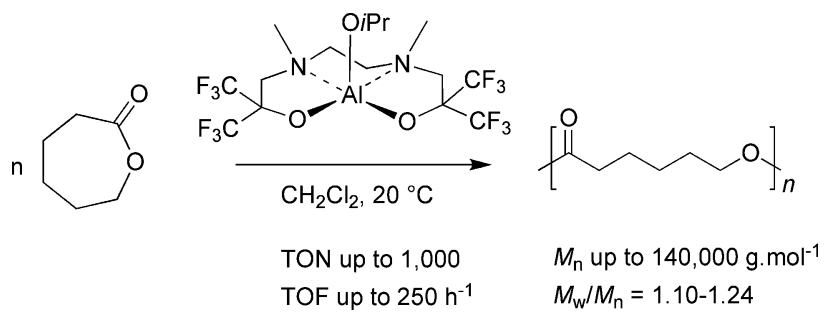

Scheme 17 Controlled ring-opening polymerization of $\varepsilon$-caprolactone promoted by $\left\{\mathrm{ON}^{\mathrm{Et}} \mathrm{NO}\right\} \mathrm{Al}(\mathrm{O} i \mathrm{Pr})$ room temperature. We hypothesized that the high polymerization activity and productivity afforded by this compound reflects a high electrophilicity/Lewis acidity of the metal center, although these properties were not independently assessed. Close agreement of the experimental molecular weights with calculated values and narrow molecular weight distributions indicated a good overall control over the polymerization. The productivity of the system and the controlled character of the polymerizations initiated by $\left\{\mathrm{ON}^{\mathrm{Et}} \mathrm{NO}\right\} \mathrm{Al}(\mathrm{O} i \mathrm{Pr})$ were further evidenced by the sequential polymerization of $350+650$ equivalents of caprolactone, for which complete conversion was observed together with minor broadening of the molecular weight distribution between the two stages.

\subsection{Fluorinated (di)alkoxy-(di)imino group 4 metal complexes}

More recently, we gained interest in a class of bidentate and tetradentate fluorinated (di)alkoxide-(di)imino ligands, which are structurally reminiscent to phenoxy-imine $e^{25,26}$ and aryloxidebearing salen ${ }^{27}$ ligands, respectively. The latter classes of ligands are nowadays ubiquitous in fine chemicals and olefin polymerization catalyses.

$\beta$-Hydroxy- $\beta$-bis(trifluoromethyl)imine $\left\{\mathrm{O}=\mathrm{N}^{\mathrm{R} 1, \mathrm{R} 2}\right\} \mathrm{H} \quad\left(\mathrm{R}^{1}=\right.$ Me, $\left.\mathrm{Ph} ; \mathrm{R}^{2}=\mathrm{Ph}, \mathrm{CH}_{2} \mathrm{Ph}\right)$ and $\operatorname{di}(\beta$-hydroxy- $\beta$-bis(trifluoromethyl))diimine $\left\{\mathrm{O}=\mathrm{N}^{\mathrm{Et}} \mathrm{N}=\mathrm{O}\right\} \mathrm{H}_{2}$ pro-ligands were prepared via a simple two-step approach: ${ }^{15}$ First, $\beta$-hydroxy- $\beta$ bis(trifluoromethyl)ketones were obtained by a catalyst-free aldol reaction between liquid hexafluoroacetone sesquihydrate and ketones (acetone, acetophenone, pinacolone); then, condensation of the latter fluorinated $\beta$-ketols with primary mono- or diamines was achieved in the presence of Lewis (montmorillonite, $\mathrm{InBr}_{3}$, $\mathrm{La}(\mathrm{OTf})_{3}$ ) or Brønsted (PTSA) acid catalysts.

The coordination chemistry of these fluorinated (di)alkoxide(di)imino ligands onto $\mathrm{Ti}(\mathrm{IV}), \mathrm{Zr}$ (IV) and $\mathrm{Hf}(\mathrm{IV})$ centers was explored, following similar synthetic strategies than those used with diamino-diols (see section 2.3.). We thus readily prepared a variety of discrete complexes of the type $\left\{\mathrm{O}=\mathrm{N}^{\mathrm{R} 1, \mathrm{R} 2}\right\}_{2} \mathrm{ZrCl}_{2}$ $\left(\mathrm{R}^{1}=\mathrm{Me}, \mathrm{Ph} ; \mathrm{R}^{2}=\mathrm{Ph}, \mathrm{C}_{6} \mathrm{~F}_{5}\right), \quad\left\{\mathrm{O}=\mathrm{N}^{\mathrm{R} 1, \mathrm{R} 2}\right\}_{2} \mathrm{Ti}(\mathrm{O} i \mathrm{Pr})_{2}$, $\left\{\mathrm{O}=\mathrm{N}^{\mathrm{R} 1, \mathrm{R} 2}\right\}_{2} \mathrm{M}\left(\mathrm{CH}_{2} \mathrm{Ph}\right)_{2}(\mathrm{M}=\mathrm{Zr}, \mathrm{Hf}),\left\{\mathrm{O}=\mathrm{N}^{\mathrm{Et}} \mathrm{N}=\mathrm{O}\right\} \mathrm{TiCl}_{2}$, and $\left\{\mathrm{O}=\mathrm{N}^{\mathrm{Et}} \mathrm{N}=\mathrm{O}\right\} \mathrm{Zr}\left(\mathrm{CH}_{2} \mathrm{Ph}\right)_{2}$ (Scheme 18). ${ }^{28} \mathrm{X}$-Ray diffraction studies revealed that those complexes are all mononuclear in the solid

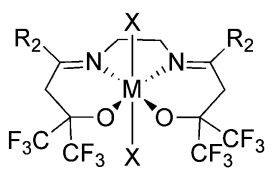

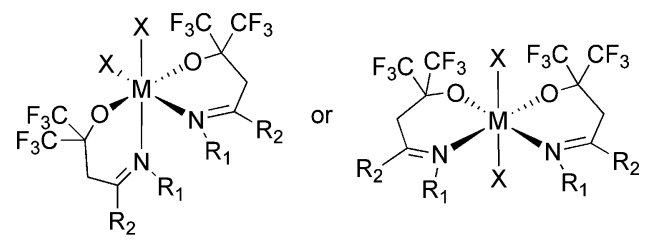

$$
\begin{gathered}
\mathrm{M}=\mathrm{Ti}, \mathrm{Zr}, \mathrm{Hf} \\
\mathrm{X}=\mathrm{Cl}, \mathrm{CH}_{2} \mathrm{Ph}, \mathrm{OiPr} \\
\mathrm{R}^{1}, \mathrm{R}^{2}=\mathrm{Me}, \mathrm{Ph}, \mathrm{CH}_{2} \mathrm{Ph}
\end{gathered}
$$

Scheme 18 Group 4 metal complexes supported by fluorinated dialkoxy-diimino ligands. 
state. They adopt either $C_{1}$ - or mostly $C_{2 v}$-symmetric, distorted octahedral structures with planar coordination of the (di)iminodi(alkoxide) ligands. Multinuclear NMR studies indicated that most of the complexes also adopt a $C_{2 \mathrm{v}}$-symmetric structure in solution. Overall, the properties of complexes $\left\{\mathrm{O}=\mathrm{N}^{\mathrm{Et}} \mathrm{N}=\mathrm{O}\right\} \mathrm{MX}_{2}$ based on tetradentate ligands appeared quite similar to those of their analogues $\left\{\mathrm{ON}^{\mathrm{Et}} \mathrm{NO}\right\} \mathrm{MX}_{2}$ based on fluorinated tetradentate dialkoxy-diamino ligands $;{ }^{23}$ an exception is the very low solubility of zirconium dichloride complexes.

Another but more relevant peculiarity we noticed in this series is the thermal instability of dibenzyl-zirconium and -hafnium complexes based on bidentate ligands, $\left\{\mathrm{O}=\mathrm{N}^{\mathrm{R} 1, \mathrm{R} 2}\right\}_{2} \mathrm{M}\left(\mathrm{CH}_{2} \mathrm{Ph}\right)_{2}$. The latter compounds decompose rapidly above $-30{ }^{\circ} \mathrm{C}$ by abstraction of an hydrogen from the methylene ligand backbone by a benzyl group, to give complexes of the type $\mathrm{M}\left(\mathrm{CH}_{2} \mathrm{Ph}\right)\left\{\mathrm{ON}^{\mathrm{R} 1 \mathrm{R} 2}\right\}\left\{\mathrm{ON}^{-\mathrm{R} 1, \mathrm{R} 2}\right\}$, in which a ligand unit has been transformed to an $\alpha, \beta$-unsaturated amido-alkoxy dianionic moiety (i.e. $\left\{\mathrm{ON}^{-\mathrm{R} 1, \mathrm{R} 2}\right\}^{2-}$ ) (Scheme 19). The pentafluorophenyl system $\left\{\mathrm{O}=\mathrm{N}^{\mathrm{Me}, \mathrm{ArF}}\right\}_{2} \mathrm{Zr}\left(\mathrm{CH}_{2} \mathrm{Ph}\right)_{2}\left(\mathrm{ArF}=\mathrm{C}_{6} \mathrm{~F}_{5}\right)$ decomposed also by hydrogen abstraction but via a slightly different process, which presumably involved preliminary ligand redistribution and ultimately yielded the benzyl-free complex $\mathrm{Zr}\left\{\mathrm{O}=\mathrm{N}^{\mathrm{Me}, \mathrm{ArF}}\right\}_{2}\left\{\mathrm{ON}^{-\mathrm{Me}, \mathrm{ArF}}\right\}$ (Scheme 20). The exact natureradical, concerted or nucleophilic - of this decomposition pathway still remains obscure. Interestingly, it did not affect the dibenzyl complex based on a tetradentate ligand such as $\left\{\mathrm{O}=\mathrm{N}^{\mathrm{Et}} \mathrm{N}=\mathrm{O}\right\} \mathrm{Zr}\left(\mathrm{CH}_{2} \mathrm{Ph}\right)_{2}$.

Some of the compounds based on bidentate ligandsł were evaluated in olefin polymerization catalysis; however, disappointing performances were observed..$^{28}$ In fact, when activated

\$ That is, those susceptible to generation of a vacant site cis to an active alkyl group, which is mandatory for olefin insertion and polymerization activity. The planar coordination of tetradentate ligands $\left\{\mathrm{O}=\mathrm{N}^{\mathrm{Et}} \mathrm{N}=\mathrm{O}\right\}^{2-}$ shall give only axial (trans) sites, which does not allow insertion and polymerization, as observed with salen-type systems. by MAO, $\left\{\mathrm{O}=\mathrm{N}^{\mathrm{R} 1, \mathrm{R} 2}\right\}_{2} \mathrm{ZrCl}_{2}$ and $\left\{\mathrm{O}=\mathrm{N}^{\mathrm{R} 1, \mathrm{R} 2}\right\}_{2} \mathrm{Ti}(\mathrm{O} i \mathrm{Pr})_{2}$ lead to active ethylene polymerization catalysts that afford very high molecular weight linear polyethylenes. However, these systems are very unstable and deactivate over a $0.1-10$ min time period. Based on the aforementioned observation of hydrogen abstraction by a benzyl group in neutral $\left\{\mathrm{O}=\mathrm{N}^{\mathrm{R} 1, \mathrm{R} 2}\right\}_{2} \mathrm{Zr}\left(\mathrm{CH}_{2} \mathrm{Ph}\right)_{2}$ species, we proposed that a similar process may take place in related cationic species [generated by the action of MAO] (Scheme 21). Hydrogen abstraction from the ligand backbone by the growing polyethylenyl chain would eventually result in the formation of an alkyl-free, and thus inactive species. In order to prevent this deactivation phenomenon, ligands having gem-dimethyl groups on the backbone have been developed; however, their coordination onto group 4 metal centers could not be achieved selectively, in contrast to aluminium (vide infra).

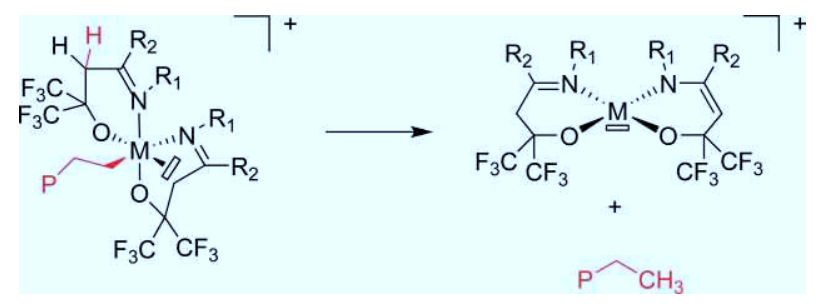

Scheme 21 Proposed decomposition pathway of active polymerization species derived from group 4 metal $\left\{\mathrm{O}=\mathrm{N}^{\mathrm{R} 1, \mathrm{R} 2}\right\}_{2} \mathrm{MX}_{2}$ precursors.

\subsection{Fluorinated dialkoxy-diimino group 3 and 13 metal complexes for lactones ring-opening polymerization catalysis}

Fluorinated dialkoxy-diimino ligands were also used to support trivalent $\mathrm{Al}(\mathrm{III}), \mathrm{Y}(\mathrm{III})$ and $\mathrm{La}(\mathrm{III})$ metal centers. A series of aluminium complexes was prepared in high yields via alkane or alcohol elimination reactions from diimino-diols $\left\{\mathrm{O}=\mathrm{N}^{\mathrm{Et}} \mathrm{N}=\mathrm{O}\right\} \mathrm{H}_{2}$ and $\left\{\mathrm{O}=\mathrm{N}^{\mathrm{Cy}} \mathrm{N}=\mathrm{O}\right\} \mathrm{H}_{2}$ and $\mathrm{AlMe}_{3}, \quad \mathrm{AlMe} \mathrm{Cl}_{2}$ or $\mathrm{Al}(\mathrm{O} i \mathrm{Pr})_{3}$

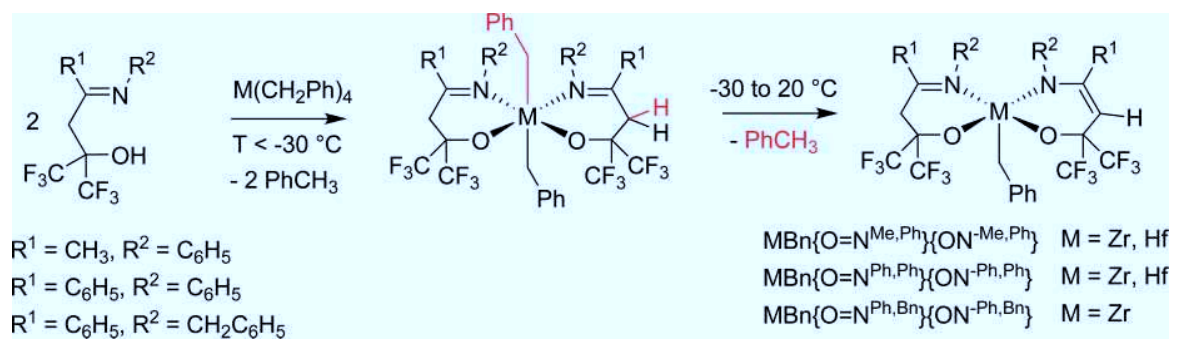

Scheme 19 Synthesis and decomposition of dibenzyl zirconium and hafnium complexes based on bidentate fluorinated alkoxy-imino ligands.
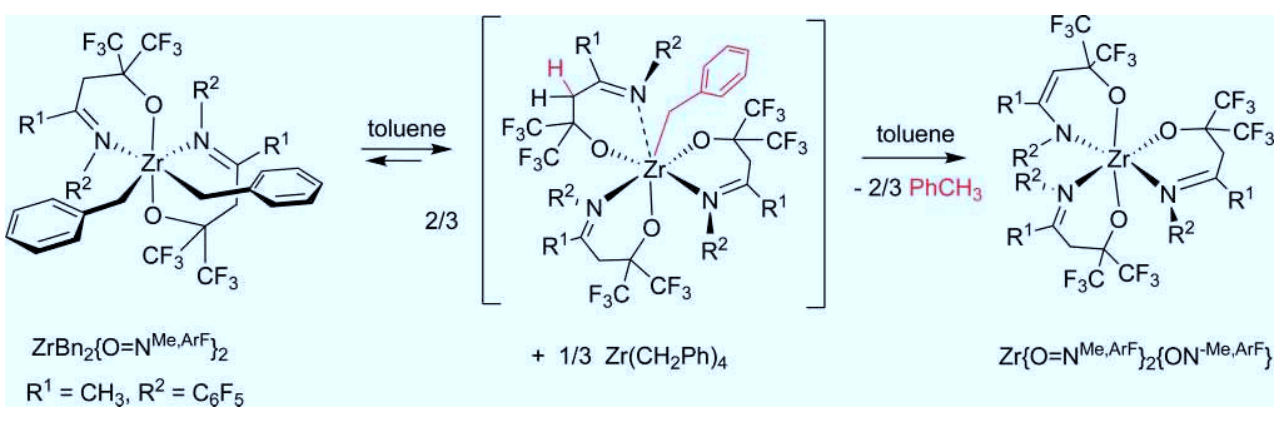

Scheme 20 Decomposition of $\left\{\mathrm{O}=\mathrm{N}^{\mathrm{Me}, \mathrm{ArF}}\right\}_{2} \mathrm{Zr}\left(\mathrm{CH}_{2} \mathrm{Ph}\right)_{2}$ complex with a putative intermediate. 
(Scheme 22). ${ }^{29}$ The obtained complexes $\left\{\mathrm{O}=\mathrm{N}^{\mathrm{Et}} \mathrm{N}=\mathrm{O}\right\} \mathrm{AlX}(\mathrm{X}=$ $\mathrm{Me}, \mathrm{Cl}, \mathrm{O} i \mathrm{Pr}),\left\{\mathrm{O}=\mathrm{N}^{\mathrm{Cy}} \mathrm{N}=\mathrm{O}\right\} \mathrm{AlX}(\mathrm{X}=\mathrm{Me}, \mathrm{Cl}, \mathrm{O} i \mathrm{Pr})$, and $\left\{{ }^{\mathrm{Me}} \mathrm{O}=\mathrm{N}^{\mathrm{Et}} \mathrm{N}=\mathrm{O}\right\}$ AlX $(\mathrm{X}=\mathrm{Me}, \mathrm{Cl})$ [the latter one is based on a gem-dimethylated ligand] all feature a mononuclear structure in the solid state, with distorted trigonal bipyramidal to square pyramidal geometries. Metrical data, i.e. Al-O, Al-N, Al-X bond distances and the corresponding bond angles, in those compounds compare well with those in Al-Salen complexes; ${ }^{27 \mathrm{f}}$ this highlights the obvious similarity of these fluorinated dialkoxydiimino ligands with salen ligands. However, the replacement of rigid phenolate rings in salen ligands by $\mathrm{sp}^{3}$-hybridized alkoxide groups in the fluorinated ligands results in larger flexibility, which likely accounts for the observed distorted geometries [Al-Salen complexes usually adopt a slightly distorted square pyramidal geometry $] .{ }^{27 e}{ }^{1} \mathrm{H},{ }^{13} \mathrm{C}$ and ${ }^{19} \mathrm{~F}$ NMR studies indicated that most of these complexes exist as a single symmetric isomer in $\mathrm{CD}_{2} \mathrm{Cl}_{2}$ solution. Only for complexes based on the bulky gem-dimethylated ligand, $\left\{{ }^{\mathrm{Me}} \mathrm{O}=\mathrm{N}^{\mathrm{Et}} \mathrm{N}=\mathrm{O}\right\} \mathrm{AlX}(\mathrm{X}=\mathrm{Me}, \mathrm{Cl})$, mixtures of two isomers (one symmetric, one dissymmetric) were observed.

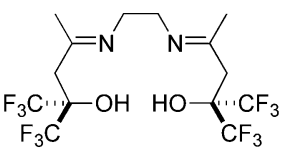

$\left\{\mathrm{O}=\mathrm{N}^{\mathrm{E}} \mathrm{N}=\mathrm{O}\right\} \mathrm{H}_{2}$

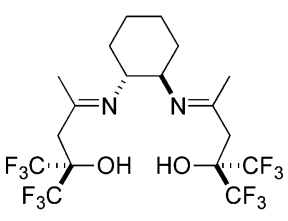

$\left\{\mathrm{O}=\mathrm{N}^{\mathrm{C}} \mathrm{N}=\mathrm{O}\right\} \mathrm{H}_{2}$

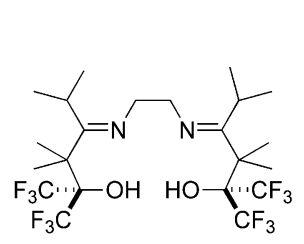

$\left\{{ }^{\mathrm{MeO}} \mathrm{O}=\mathrm{N}^{\mathrm{Et}} \mathrm{N}=\mathrm{O}\right\} \mathrm{H}_{2}$

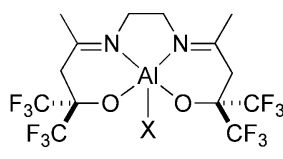

$\mathrm{X}=\mathrm{Me}, \mathrm{Cl}, \mathrm{OiPr}$

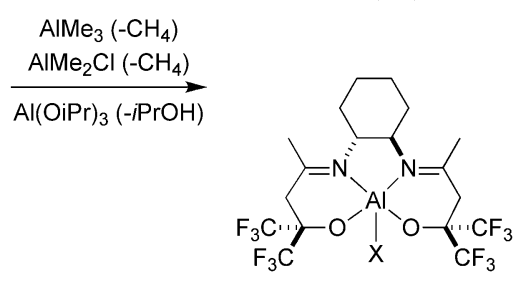

$\mathrm{X}=\mathrm{Me}, \mathrm{Cl}, \mathrm{OiPr}$

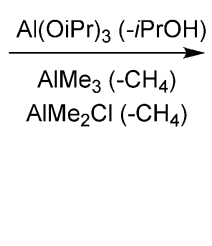

$\mathrm{X}=\mathrm{Me}, \mathrm{Cl}$

Scheme 22 Aluminium complexes supported by tetradentate fluorinated dialkoxy-diimino ligands.

The preparation of yttrium and lanthanum complexes derived from the diimino-diol $\left\{\mathrm{O}=\mathrm{N}^{\mathrm{Et}} \mathrm{N}=\mathrm{O}\right\} \mathrm{H}_{2}$ was similarly conducted. ${ }^{30}$ Amine elimination reactions from $\mathrm{La}\left(\mathrm{N}\left(\mathrm{SiHMe}_{2}\right)_{2}\right)_{3} \cdot(\mathrm{THF})_{2}$ or $\mathrm{La}\left(\mathrm{N}\left(\mathrm{SiMe}_{3}\right)_{2}\right)_{3}$ systematically yielded the "homoleptic" complex $\left\{\mathrm{O}=\mathrm{N}^{\mathrm{Et}} \mathrm{N}=\mathrm{O}\right\} \mathrm{La}-$ $\left\{\mathrm{O}=\mathrm{N}^{\mathrm{E} t} \mathrm{~N}=\mathrm{OH}\right\}$. The large ionic radius of $\mathrm{La}(\mathrm{III})$ probably accounts for the instability of the putative intermediate heteroleptic amido species. On the other hand, the yttriumamido complex $\left\{\mathrm{O}=\mathrm{N}^{\mathrm{Et}} \mathrm{N}=\mathrm{O}\right\} \mathrm{Y}\left(\mathrm{N}\left(\mathrm{SiHMe}_{2}\right)_{2}\right)(\mathrm{THF})$ proved to be somewhat more stable and could be in turn transformed upon reaction with 1 equivalent of $(R)$-tert-butyl lactate to give selectively $\left[\left\{\mathrm{O}=\mathrm{N}^{\mathrm{Et}} \mathrm{N}=\mathrm{O}\right\} \mathrm{Y}((R)-t \mathrm{Bu}-\text { lactate) }]_{2}\right.$ (Scheme 23). The latter compound, a rare example of a rare earth lactate complex, ${ }^{31}$ is dinuclear in the solid state, with bridging

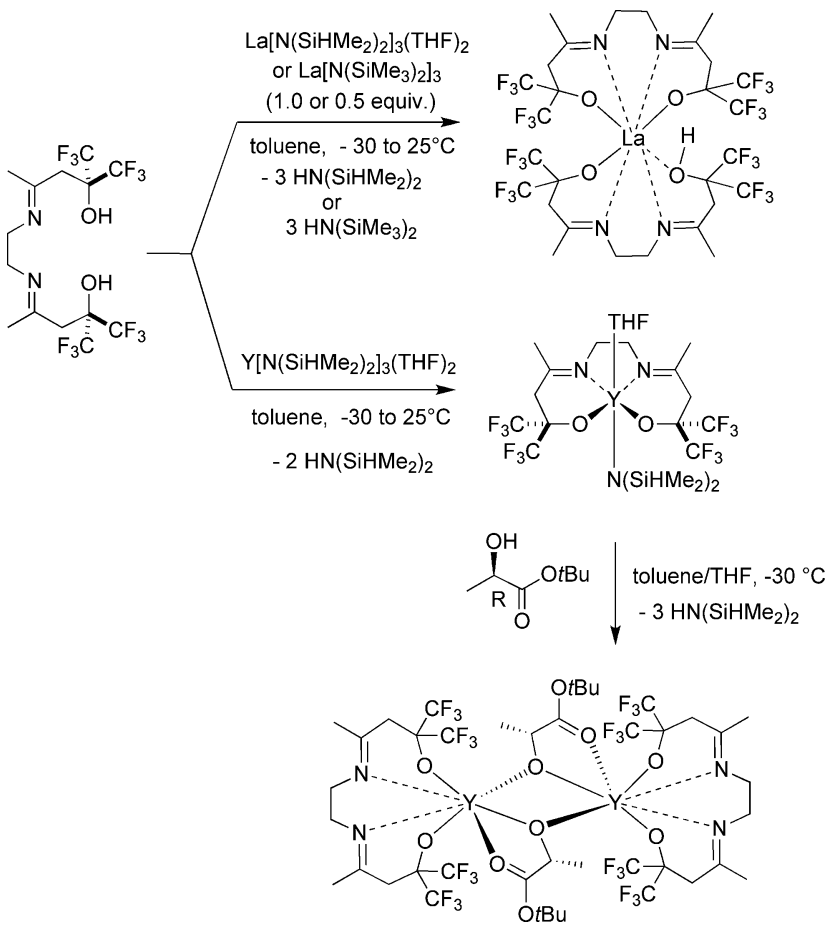

Scheme 23 Synthesis of rare earth metal complexes supported by tetradentate fluorinated dialkoxy-diimino ligands.

$\mu, \kappa^{2}-O, O, O$-lactate units and tetracoordinated $\left\{\mathrm{O}=\mathrm{N}^{\mathrm{Et}} \mathrm{N}=\mathrm{O}\right\}$ units. NMR studies confirmed that this geometry is retained in THF solution.

This yttrium-lactate complex is an effective initiator for the controlled "living" ring-opening polymerization of rac-lactide and rac- $\beta$-butyrolactone under mild conditions (room temperature) (Scheme 24). ${ }^{30}$ This catalyst offers atactic polymers with high molecular weights that match the calculated values well, and relatively narrow polydispersities $\left(M_{\mathrm{w}} / M_{\mathrm{n}}=1.06-1.60\right)$. The overall performance in terms of control over the molecular weights of the polymers and molecular weight distributions compare well those of related alkoxide Y(III) complexes supported by bis(phenolate)-type ligands having additional donor atoms ( $\mathrm{N}$, $\mathrm{O}, \mathrm{S}) .^{31,32}$ Its catalytic activity appears, however, somewhat lower than with these bis(phenolate)-yttrium alkoxide complexes. We assumed that this might reflect the lower nucleophilicity of the lactate unit, possibly as an indirect influence of the strong electronwithdrawing of the fluorinated dialkoxide-diimino ligand.

Isopropoxide complexes $\left\{\mathrm{O}=\mathrm{N}^{\mathrm{R}} \mathrm{N}=\mathrm{O}\right\} \mathrm{AlO} i \operatorname{Pr}(\mathrm{R}=$ ethylenyl, 1,2-cyclohexenyl) are also effective initiators for the ROP of $\varepsilon$-caprolactone and rac-lactide, in solution or in the melted monomer. ${ }^{29}$ These catalysts provide PCL and PLA polymers with high molecular weights, in good agreement with calculated values, and relatively narrow polydispersities $\left(M_{\mathrm{w}} / M_{\mathrm{n}}=1.08\right.$ 1.91) (Scheme 25). These data are indicative of a single-site, living-type behavior. The first interesting feature of these systems is the observed high dependence of activities in the ROP of lactide with the nature of substituents on the ligand backbone. In fact, much higher activities were obtained with the ethylenebridged system (TOFs up to $1260 \mathrm{~h}^{-1}$ at $120{ }^{\circ} \mathrm{C}$ ), while the cyclohexylene-bridged system is significantly less active (TOFs of $2-3 \mathrm{~h}^{-1}$ at $130{ }^{\circ} \mathrm{C}$ and up to $1000 \mathrm{~h}^{-1}$ at $170{ }^{\circ} \mathrm{C}$ ). Another most 

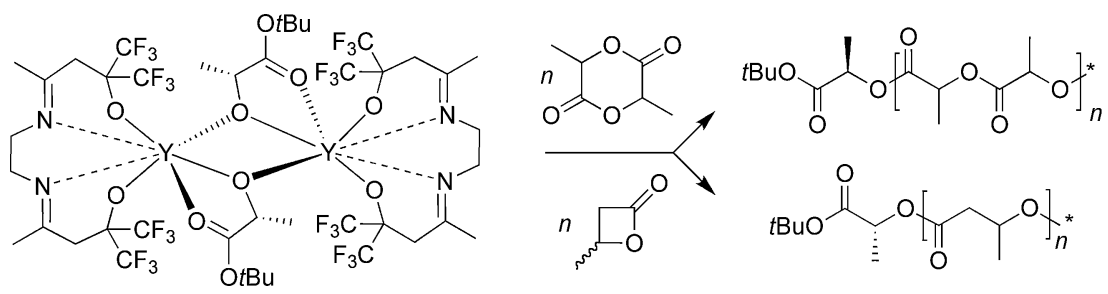

Scheme 24 Ring-opening polymerization of racemic lactide and $\beta$-butyrolactone to produce atactic polymers.

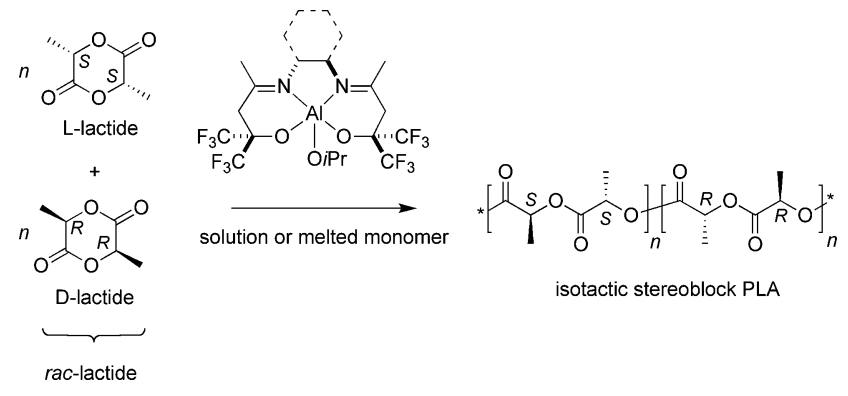

Scheme 25 Stereoselective ring-opening polymerization of racemic lactide with $\left\{\mathrm{O}=\mathrm{N}^{\mathrm{R}} \mathrm{N}=\mathrm{O}\right\} \mathrm{AlO} i \mathrm{Pr}$ complexes.

interesting feature is the significant level of isotacticity induced in the ROP of rac-lactide: The PLAs produced, under slurry or melt conditions, with either achiral complex $\left\{\mathrm{O}=\mathrm{N}^{\mathrm{Et}} \mathrm{N}=\mathrm{O}\right\} \mathrm{AlO} i \mathrm{Pr}$ or chiral complex $\left\{\mathrm{O}=\mathrm{N}^{\mathrm{Cy}} \mathrm{N}=\mathrm{O}\right\} \mathrm{AlO} i \mathrm{Pr}$, have a highly isotacticenriched stereoblock microstructure $\left(P_{\text {meso }}=0.87\right) .{ }^{33}$

\subsection{Mixed fluorinated alkoxy-phenoxy-diimino group 3 and $\mathbf{1 3}$ metal complexes for ring-opening polymerization catalysis of lactones}

We have recently developed an effective entry towards an unusual mixed fluorinated alkoxy/phenoxy Schiff base ligand $\left(\left\{{ }^{\mathrm{Ar}} \mathrm{O}=\mathrm{N}^{\mathrm{Cy}} \mathrm{N}=\mathrm{O}^{\mathrm{CF}_{3}}\right\}^{2-}\right){ }^{34}$ Such a ligand effectively supports $\mathrm{Al}(\mathrm{III})$ and $\mathrm{Y}(\mathrm{III})$ metal centers, leading via the same aforementioned synthetic procedures to discrete mononuclear complexes $\left.\quad{ }^{\mathrm{Ar}} \mathrm{O}=\mathrm{N}^{\mathrm{Cy}} \mathrm{N}=\mathrm{O}^{\mathrm{CF}_{3}}\right\} \mathrm{AlX} \quad(\mathrm{X}=\mathrm{Cl}, \mathrm{O} i \mathrm{Pr})$ and $\left\{{ }^{\mathrm{Ar}} \mathrm{O}=\mathrm{N}^{\mathrm{Cy}} \mathrm{N}=\mathrm{O}^{\mathrm{CF}_{3}}\right\} \mathrm{Y}\left(\mathrm{N}\left(\mathrm{SiHMe}_{2}\right)_{2}\right)(\mathrm{THF})$ in high yields (Scheme 26). Those aluminium and yttrium complexes are mononuclear in the solid state with five-coordinated distorted square pyramidal and six-coordinated distorted octahedral geometries, respectively. The amount of distortion towards a

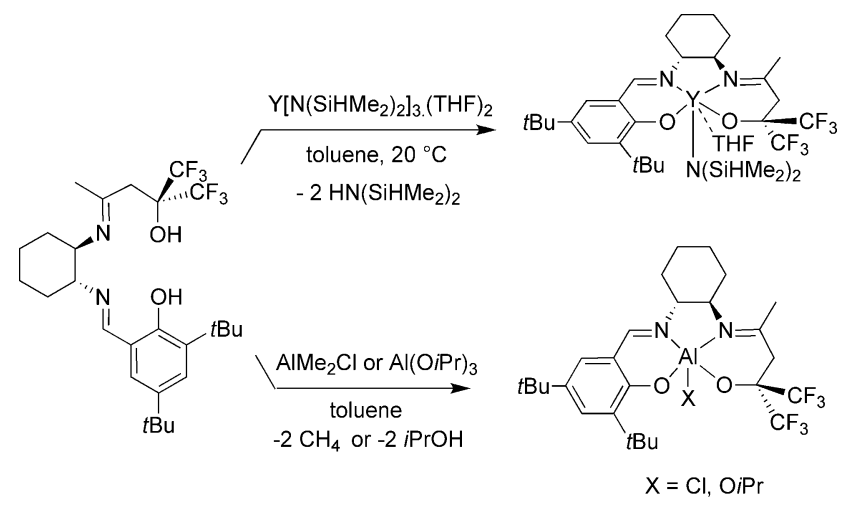

Scheme 26 Synthesis of yttrium and aluminium complexes supported by a tetradentate mixed fluorinated alkoxy-phenoxy-diimino ligand. trigonal bipyramidal (tbp) geometry in $\left\{{ }^{\mathrm{Ar}} \mathrm{O}=\mathrm{N}^{\mathrm{Cy}} \mathrm{N}=\mathrm{O}^{\mathrm{CF}_{3}}\right\} \mathrm{AlCl}$ $\left(\tau=0.12^{35}\right)$ is significantly lower than that observed for $\left\{\mathrm{O}=\mathrm{N}^{\mathrm{R}} \mathrm{N}=\mathrm{O}\right\} \mathrm{AlX}$ complexes based on symmetric fluorinated dialkoxy-diimino ligands ( $\tau=0.42-0.85$ ). Obviously, the replacement of a sp $\mathrm{s}^{3}$-hybridized bis(trifluoromethyl)alkoxy group in the latter complexes by a phenolate moiety conjugated with the imino function in $\left\{{ }^{\mathrm{Ar}} \mathrm{O}=\mathrm{N}^{\mathrm{Cy}} \mathrm{N}=\mathrm{O}^{\mathrm{CF}_{3}}\right\} \mathrm{AlCl}$ induces a more rigid ligand backbone and, as a result, the geometry around the metal center changes from tbp to sqp. Note that both aluminium and yttrium complexes exist as a single isomer in benzene solution at room temperature, as evidenced by NMR studies.

The performances of these complexes were evaluated in the ROP of $r a c$-lactide. The yttrium-amido complex is active at room temperature, but the recovered PLAs were atactic and showed relatively broad molecular weight distributions. This was assumed to reflect, at least in part, the poor initiation efficiency of the amido group; metal-amides are actually known to be less nucleophilic than other initiating groups such as alkoxides. ${ }^{32}$ The aluminium isopropoxide complex $\left\{{ }^{\mathrm{Ar}} \mathrm{O}=\mathrm{N}^{\mathrm{Cy}} \mathrm{N}=\mathrm{O}^{\mathrm{CF}_{3}}\right\} \mathrm{AlO} i \mathrm{Pr}$ complex is an effective initiator, showing activities similar to those observed with $\left\{\mathrm{O}=\mathrm{N}^{\mathrm{Cy}} \mathrm{N}=\mathrm{O}\right\} \mathrm{Al}(\mathrm{O} i \mathrm{Pr})$ that bears a symmetric fluorinated dialkoxy-diimino ligand. The PLAs recovered had quite narrow polydispersities with experimental $M_{\mathrm{n}}$ values that match well those calculated for a living polymerization. These reactions led to the formation of significantly isotactic-enriched stereoblock PLAs $\left(P_{\text {meso }}=0.87\right)$, which are essentially similar to those observed with $\left\{\mathrm{O}=\mathrm{N}^{\mathrm{Cy}} \mathrm{N}=\mathrm{O}\right\} \mathrm{Al}(\mathrm{O} i \mathrm{Pr})$ (vide supra).

\section{Concluding remarks}

Fluorinated alkoxy-amino and alkoxy-imino ligands have been known for about 25 years. It is worth mentioning that since they were first produced by template synthesis, early work immediately pointed at their pertinence for coordination chemistry. This interest was rapidly recognized and successfully exploited for materials precursors, thanks to the stability and relative volatility that those classes of ligands confer to related metal complexes.

The use of such ligands to develop well-defined, discrete complexes for single-site catalysis will obviously require much more expansion before reaching maturity. Our preliminary investigations summarized in this review, as well as more recent works on Zn complexes, ${ }^{36}$ confirmed that ubiquitous phenoxy (phenolate) ligands can be, in principle, easily substituted by $\mathrm{OC}\left(\mathrm{CF}_{3}\right)_{2} \mathrm{CR}_{2}$ type moieties. In particular, analogues of the salen ligands can be accessed and offer new opportunities to tune this fantastic class of Schiff base ligands, to further improve performances and expand reactions scope, e.g. in asymmetric catalysis. In this regard, the latest mixed fluorinated alkoxy/phenolate ligand platforms may hold good promise, by offering the possibility to sterically and 
electronically differentiated coordination sites at a variety of metal centers.

\section{Note added in proof}

Quite recently, Kol et al. reported on the synthesis of a chiral tetradentate dianionic fluorinated diolate-diamine ligand assembled around 2,2'-bipyrrolidine. ${ }^{37}$ This ligand wraps diastereoselectively in a fac-fac helical mode around octahedral titanium and zirconium centers, giving chiral-at-metal complexes as (enantiomerically pure) single diastereomers.

\section{Acknowledgements}

I gratefully thank all colleagues, PhD students and post-doc associates who contributed to this work, and whose names appear in the references. This work was supported in part by the CNRS, Institut Universitaire de France, the French Ministry of Research and Higher Education, ANR and Total Petrochemicals.

\section{References}

1 For reviews on alkoxo- and aryloxo-metal chemistry, see: $(a)$ D. C. Bradley, R. M. Mehrotra, I. P. Rothwell and A. Singh, Alkoxo and Aryloxo Derivatives of Metals, Academic Press, London, 2001; (b) R. M. Mehrotra and A. Singh, Prog. Inorg. Chem., 1997, 46, 239; (c) L. G. Hubert-Pfalzgraf, Coord. Chem. Rev., 1998, 178-180, 967; (d) W.E. Piers and D. J. H. Emslie, Coord. Chem. Rev., 2002, 233-234, 131; (e) F. T. Edelmann, D. M. M. Freckmann and H. Schumann, Chem. Rev., 2002, 102, 1851.

2 For selected examples of early transition metal complexes bearing fluorinated alkoxide ligands, see: (a) D. C. Bradley, H. Chudszynska, M. B. Hursthouse and M. Motevalli, Polyhedron, 1993, 12, 1907; (b) D. C. Bradley, H. Chudszynska, M. B. Hursthouse and M. Motevalli, Polyhedron, 1994, 13, 7; (c) J. A. Samuels, E. B. Lobkovsky, W. E. Streib, K. Folting, J. C. Huffman, J. W. Zwanziger and K. G. Caulton, J. Am. Chem. Soc., 1993, 115, 5093.

3 See, for instance: (a) A. Decken, G. B. Nikiforov and J. Passmore, Dalton Trans., 2006, 4328; (b) K. C. Molloy and P. A. Williams, Appl. Organomet. Chem., 2008, 22, 560 .

4 (a) R. R. Schrock, R. T. DePue, J. Feldman, C. J. Schaverien, J. C. Dewan and A. H. Liu, J. Am. Chem. Soc., 1988, 110, 1423; (b) R. R. Schrock, J. S. Murdzek, G. C. Bazan, J. Robbins, M. DiMare and M. O'Regan, J. Am. Chem. Soc., 1990, 112, 3875.

5 (a) O. Fujimura and R. J. Grubbs, J. Am. Chem. Soc., 1996, 118, 2499; (b) O. Fujimura, F. J. De la Mata and R. H. Grubbs, Organometallics, 1996, 15, 1865.

6 T. Tsukuhara, D. C. Swenson and R. F. Jordan, Organometallics, 1997, 16, 3303.

7 (a) J. W. L. Martin and C. J. Willis, Can. J. Chem., 1977, 55, 2459; (b) J. H. Timmons, J. W. L. Martin, A. E. Martell, P. Rudolf, A. Clearfield, J. H. Arner, S. J. Loeb and C. J. Willis, Inorg. Chem., 1980, 19, 3553; (c) E. Konefal, S. J. Loeb, D. W. Stephan and C. J. Willis, Inorg. Chem., 1984, 23, 538 .

8 S. J. Loeb, D. W. Stephan and C. J. Willis, Inorg. Chem., 1984, 23, 1509.

9 J. W. L. Martin, N. C. Payne and C. J. Willis, Inorg. Chem., 1978, 17, 3478 .

10 D. L. Barber, S. J. Loeb, J. W. L. Martin, N. C. Payne and C. J. Willis, Inorg. Chem., 1981, 20, 272.

11 (a) S. J. Loeb, J. W. L. Martin and C. J. Willis, Inorg. Chem., 1979, 18, 3160; (b) J. H. Timmons, J. W. L. Martin, A. E. Martell, P. Rudolf, A. Clearfield, S. J. Loeb and C. J. Willis, Inorg. Chem., 1981, 20, 181.

12 S. J. Loeb and C. J. Willis, Inorg. Chem., 1981, 20, 2791.

13 S. J. Loeb, J. F. Richardson and C. J. Willis, Inorg. Chem., 1983, 22, 2736.

14 J. W. L. Martin and C. J. Willis, Can. J. Chem, 1977, 55, 2459.
15 N. Marquet, E. Grunova, E. Kirillov, M. Bouyahyi, C. M. Thomas and J.-F. Carpentier, Tetrahedron, 2008, 64, 75.

16 Y.-H. Liu, Y.-C. Cheng, Y.-L. Tung, Y. Chi, Y.-L. Chen, C.-S. Lui, S.-M. Peng and G.-H. Lee, J. Mater. Chem., 2003, 13, 135.

17 Y.-L. Chen, C.-C. Hsu, Y.-H. Song, Y. Chi, A. J. Carty, S.-M. Peng and G.-H. Lee, Chem. Vap. Deposition, 2006, 12, 442.

18 Y.-H. Lai, T.-Y. Chou, Y.-H. Song, C.-S. Liu, Y. Chi, A. J. Carty, S.-M. Peng and G.-H. Lee, Chem. Mater., 2003, 15, 2454.

19 (a) Y. Chi, P.-F. Hsu, C.-S. Liu, W.-L. Ching, T.-Y. Chou, A. J. Carty, S.-M. Peng, G.-H. Lee and S.-H. Chuang, J. Mater. Chem., 2002, 12, 3541; (b) E. Lay, Y.-H. Song, Y.-C. Chiu, Y.-M. Lin, Y. Chi, A. J. Carty, S.-M. Peng and G.-H. Lee, Inorg. Chem., 2005, 44, 7226.

20 Y. Chi, T.-Y. Chou, Y.-J. Wang, S.-F. Huang, A. J. Carty, L. Scoles, K. A. Udachin, S.-M. Peng and G.-H. Lee, Organometallics, 2004, 23, 95.

21 Y. Chi, S. Ranjan, T.-Y. Chou, C.-S. Liu, S.-M. Peng and G.-H. Lee, J. Chem. Soc., Dalton Trans., 2001, 2462.

22 (a) L. Lavanant, A. Silvestru, A. Faucheux, L. Toupet, R. F. Jordan and J.-F. Carpentier, Organometallics, 2005, 24, 5604; (b) L. Lavanant, L. Toupet, C. W. Lehmann and J.-F. Carpentier, Organometallics, 2005, 24, 5620 .

23 (a) L. Lavanant, T.-Y. Chou, Y. Chi, C. W. Lehmann, L. Toupet and J.-F. Carpentier, Organometallics, 2004, 23, 5450; (b) E. Kirillov, L. Lavanant, C. M. Thomas, T. Roisnel, Y. Chi and J.-F. Carpentier, Chem.-Eur. J., 2007, 13, 923.

24 A. Amgoune, L. Lavanant, C. M. Thomas, Y. Chi, R. Welter, S. Dagorne and J.-F. Carpentier, Organometallics, 2005, 24, 6279.

25 (a) T. Matsugi and F. Fujita, Chem. Soc. Rev., 2008, 37, 1264; (b) M. Mitani, T. Nakano and T. Fujita, Chem.-Eur. J., 2003, 9, 2396; (c) M. Mitani, R. Furuyama, J. Mohri, J. Saito, S. Ishii, H. Terao, T. Nakano, H. Tanaka and T. Fujita, J. Am. Chem. Soc., 2003, 125, 4293; (d) M. Mitani, R. Furuyama, J. Mohri, J. Saito, S. Ishii, H. Terao, N. Kashiwa and T. Fujita, J. Am. Chem. Soc., 2002, 124, 7888; (e) J. Saito, M. Mitani, J. Mohri, Y. Yoshida, S. Matsui, S. Ishii, S. Kojoh, N. Kashiwa and T. Fujita, Angew. Chem., Int. Ed., 2001, 40, 2918.

26 (a) A. F. Mason and G. W. Coates, J. Am. Chem. Soc., 2004, 126, 10798; (b) A. F. Mason and G. W. Coates, J. Am. Chem. Soc., 2004, 126, 16326; (c) P. D. Hustad, J. Tian and G. W. Coates, J. Am. Chem. Soc., 2002, 124, 3614; (d) J. Tian and G. W. Coates, Angew. Chem., Int. Ed., 2000, 39, 3626.

27 (a) E. N. Jacobsen, Comprehensive Organometallic Chemistry II, ed. G. Wilkinson, F. G. A. Stone, E. W. Abel and L. S. Hegedus, Pergamon Press, New York, 1995, vol. 12, ch. 11.1; (b) J. F. Larrow and E. N. Jacobsen, Top. Organomet. Chem., 2004, 6, 123; (c) P. G. Cozzi, Chem. Soc. Rev., 2004, 33, 410; (d) T. Katsuki, Chem. Soc. Rev., 2004, 33, 437; (e) D. A. Atwood and M. J. Harvey, Chem. Rev., 2001, 101, 37.

28 N. Marquet, E. Kirillov, T. Roisnel, A. Razavi and J.-F. Carpentier, Organometallics, 2009, 28, 606.

29 M. Bouyahyi, E. Grunova, N. Marquet, E. Kirillov, C. M. Thomas, T. Roisnel and J.-F. Carpentier, Organometallics, 2008, 27, 5815.

30 E. Grunova, E. Kirillov, T. Roisnel and J.-F. Carpentier, Organometallics, 2008, 27, 5691.

31 H. Ma, T. P. Spaniol and J. Okuda, Angew. Chem., Int. Ed., 2006, 45, 7818.

32 (a) C.-X. Cai, A. Amgoune, C. W. Lehmann and J.-F. Carpentier, Chem. Commun., 2004, 330; (b) A. Amgoune, C. M. Thomas, T. Roisnel and J.-F. Carpentier, Chem.-Eur. J., 2006, 12, 169; (c) A. Amgoune, C. M. Thomas, S. Ilinca, T. Roisnel and J.-F. Carpentier, Angew. Chem., Int. Ed., 2006, 45, 2782; (d) A. Amgoune, C. M. Thomas and J.-F. Carpentier, Macromol. Rapid Commun., 2007, 28, 693; (e) A. Amgoune, C. M. Thomas and J.-F. Carpentier, Pure Appl. Chem., 2007, 79, 2013.

33 The parameter $P_{\text {meso }}$ is the probability of forming a new meso-linkage. See: J. E. Kasperczyk, Macromolecules, 1995, 28, 3937.

34 A. Alaaeddine, C. Thomas, T. Roisnel and J.-F. Carpentier, Organometallics, 2009, 28, 1469.

35 The $\tau$ value ranges from 0 (perfectly square pyramidal) to 1 (perfectly trigonal bipyramidal). $\alpha$ and $\beta$ are the angles that are opposite each other in the $x y$ plane (with the Al-X group oriented along the $z$ axis). A. W. Addison, T. N. Rao, J. Reedjik, J. van Rijn and G. C. Verschoor, J. Chem. Soc., Dalton Trans., 1984, 1349.

36 E. Grunova, T. Roisnel and J.-F. Carpentier, Dalton Trans., 2009, DOI: $10.1039 / \mathrm{b} 902087 \mathrm{j}$.

37 E. Sergeeva, J. Kopilov, I. Goldberg and M. Kol, Inorg. Chem., 2009, 48, 8075 . 